\title{
A Exposição Antropológica Brasileira de 1882 e a exibição de índios botocudos: performances de primeiro contato em um caso de zoológico humano brasileiro
}

The Brazilian Anthropological Exhibition (1882) and the presentation of Botocudo Indians: first contact performances in a Brazilian human zoo case

Marina Cavalcante Vieira*

* Universidade do Estado do Rio de Janeiro - Rio de Janeiro, RJ, Brasil

Doutoranda em Ciências Sociais (bolsista Capes)

marina.cavalcante.vieira@gmail.com

https://orcid.org/0000-0003-3764-6828 


\title{
Resumo
}

Este artigo remonta a Exposição Antropológica Brasileira, exibida no Segundo Império, no ano de 1882, no Museu Nacional do Rio de Janeiro. Convido o leitor a interpretar esse evento pouco lembrado da história brasileira, com o intuito de reconstituir a apresentação de sete índios botocudos, levados à corte com a finalidade de serem expostos ao público e ao mesmo tempo estudados pelos pesquisadores do Museu Nacional. Finda a participação dos índios botocudos na referida exposição, publica-se a notícia de que alguns destes mesmos índios teriam sido enviados para a Europa, gerando acaloradas discussões na imprensa nacional. A partir de documentos institucionais do Museu Nacional e reportagens de jornais da época, lança-se luz sobre o fenômeno das grandes exposições antropológicas de finais do século XIX, aqui entendidas como zoológicos humanos. Diante desse evento e da prática de colecionamento e tráfico de pessoas e objetos etnográficos, abre-se um espelho, desde o qual se pode vislumbrar a formação da antropologia brasileira e questões fundamentais à identidade nacional.

Palavras-chave: coleções etnográficas; Exposição Antropológica Brasileira; zoológicos humanos; Botocudos.

\begin{abstract}
This article reconstitutes the Brazilian Anthropological Exhibition, displayed in the Second Empire, in the year 1882, at the National Museum of Rio de Janeiro. The reader it is invited to interpret this forgotten event of Brazilian history, with the intention of reconstituting the presentation of seven Botocudo Indians, brought to court for the purpose of being exposed to the public and at the same time analyzed by the researchers of the National Museum. After the participation of the Botocudo Indians in this exhibition, it is published in the news that some of these same Indians had been sent to Europe, generating heated discussions in the national press. From institutional documents of the National Museum and newspaper reports of the time, this article sheds light on the phenomenon of great anthropological exhibitions of the late nineteenth century, understood here as human zoos. Before this event and the practice of collecting and trafficking people and ethnographic objects, a mirror is opened, from which one can glimpse the formation of Brazilian anthropology and fundamental questions to the national identity.
\end{abstract}

Keywords: ethnographic collections; Brazilian Anthropological Exhibition; human zoos; Botocudo. 


\section{Introdução ${ }^{1}$}

A Exposição Antropológica Brasileira foi inaugurada no sábado, 29 de julho de 1882 no Museu Nacional, à época localizado no Campo de Santana, na cidade do Rio de Janeiro. Houve uma solenidade de abertura às 11 horas da manhã, com a presença da família imperial, composta pelo imperador Dom Pedro II, a imperatriz Teresa Cristina e a princesa Isabel, além de figuras ilustres da sociedade carioca. A inauguração foi programada para coincidir com o calendário das festividades do aniversário da princesa Isabel, e foi declarado feriado nacional. ${ }^{2}$

A exposição vinha sendo frequentemente anunciada nos jornais, o que explica por que "antes da hora marcada, já era grande a affluencia dos convidados, que percorriam as vastas salas adornadas com a simplicidade de que requerem as festas da sciencia" (O Despertador, 1882b, p. 2). Exibição que mistura ciência e espetáculo, uma "festa da sciencia", anunciada oficialmente pelo Museu Nacional como evento científico e festejada pelos jornais como entretenimento. No centro desse espetáculo estava a "família" de índios botocudos, ${ }^{3}$ composta por sete membros, constantemente mencionada nos jornais como a grande atração do evento, embora sequer citados nos documentos oficiais de divulgação do Museu Nacional, tais como o Guia da Exposição Anthropologica Brazileira (1882), de cerca de 70 páginas. ${ }^{4}$

1 O presente trabalho foi realizado com apoio da Coordenação de Aperfeiçoamento de Pessoal de Nível Superior - Brasil (Capes) - Código de Financiamento 001.

2 A exposição havia sido primeiramente programada para inaugurar no dia 2 de dezembro de 1881, como um evento simultâneo e complementar à Exposição de História do Brasil, em seguida remarcada para 14 de março de 1882 e finalmente inaugurada em 29 de julho de 1882.

3 "Botocudo" era um termo generalizante, utilizado pelos colonizadores portugueses para denominar indistintamente etnias indígenas que utilizavam "botoques" ou alargamentos labiais. Os sete índios expostos no Rio de Janeiro denominavam-se como Nak-Nanuk, do tronco linguístico Krenak.

4 O Guia da Exposição Anthropologica Brazileira faz referência a pinturas a óleo expostas na Sala Anchieta. Em suas descrições há a referência às etnias e algumas obras contêm nome dos sujeitos retratados, por ser um padrão adotado pelos artistas em questão, Décio Villares e Aurélio de Figueiredo (Borges; Botelho, 2012). A partir desse documento depreendem-se alguns de seus nomes: "Menino Thomé, botocudo Nak-nanuk, do rio Doce; de 8 annos de edade; em busto. Pintado a oleo do natural por Decio Villares [...]. Thomaré, botocuda Nak-nanuk, do rio Doce; de 60 annos de edade; em busto. Pintado a oleo do natural por Decio Villares [...]. Nazareno, Botocudo Nak-nanuk, do rio Doce; de 16 annos de edade; em busto. Pintado a oleo do natural por Decio Villares" (Guia..., 1882, p 65). O Diario do Brazil de 7 de julho de 1882 critica a maneira como os $\rightarrow$ 
A Exposição Antropológica Brasileira insere-se no quadro das grandes Exposições Internacionais, bem como das exposições etnográficas desenvolvidas ao longo do século XIX. Marcadas pela prática colecionista e pela ambição de conhecer, colonizar e categorizar o mundo, as exposições etnográficas expunham objetos e muitas vezes pessoas de culturas exóticas e distantes. Em uma revisão historiográfica, ${ }^{5}$ tais exposições têm sido conceituadas como zoológicos humanos, embora para os seus contemporâneos fossem denominadas de shows etnográficos, exibições antropológicas ou shows étnicos. Opta-se pelo uso do termo zoológico humano, entendido aqui como um conceito, na medida em que, para os ouvidos do século XXI, "exibição etnográfica" é um termo demasiado científico ou asséptico, não tendo na língua portuguesa contemporânea o referente ao mesmo tempo racialista e de entretenimento que tinha para os homens e mulheres do século XIX. ${ }^{6}$ Desenvolvidos na junção entre o colonialismo e a formação da cultura de massa, os zoológicos humanos tomam forma no último quartel do século XIX,7 combinando funções de espetáculo, performance, educação e dominação.

A exibição de povos ditos bárbaros aconteceu desde Roma, por exemplo, assim como desde as navegações no século XV. Havia o modus operandi de levar não apenas matérias-primas, fauna e flora de locais "descobertos". Pessoas eram levadas para a Europa como suvenires. No entanto, vê-las era um "privilégio" geralmente restrito ao rei e sua corte. O que vemos surgir no século XIX são espetáculos para as massas, com a construção de cenografias, hábitats e

$\rightarrow$ índios estariam alojados no Campo de Santana, além de ser o único jornal a publicar os nomes desses índios. Segundo esta fonte, os homens se chamavam Capitão Joaquim Pedro, José, Nazareth e Thomé, e as três mulheres seriam Maréca, Aquinhen e Benta (Diario do Brazil, 1882a, p. 2).

5 A literatura sobre o tema dos zoológicos humanos tem sido desenvolvida a partir de uma revisão histórica dentro do quadro dos estudos pós-coloniais. O referido termo foi cunhado por um grupo de historiadores franceses no ano de 2002, com a publicação de Zoos humains: de la Vénus hottentote aux reality shows, livro organizado por Pascal Blanchard, Nicolas Bancel, Gilles Boëtsch, Éric Deroo e Sandrine Lemaire (Blanchard et al., 2002).

6 O termo análogo ao nosso "exibição etnográfica" em alemão, Völkerschau, carrega esta dimensão colonialista e racialista.

7 Em 1874 o alemão Carl Hagenbeck, reconhecido como um dos maiores vendedores de animais do mundo, resolve entrar para o negócio dos shows étnicos ou Völkerschauen, que ele passa a chamar de exibições zooantropológicas ou anthropologische-zoologische Ausstellung, ao remontar hábitats com animais, flora e "pessoas exóticas". Ver Ames (2008) e Thode-Arora (1989). 
encenação. A partir daí desenvolve-se um novo conceito de entretenimento, que geralmente envolvia a recriação de vilas, rituais e vida cotidiana.

Grande parte da literatura que se debruça sobre a Exposição Antropológica Brasileira de 1882 aborda o evento diante do panorama da formação de instituições científicas no Brasil ou ainda da história da antropologia física e trajetória de seus intelectuais e pesquisadores. ${ }^{8}$ Este artigo analisa o evento científico sob a perspectiva dos zoológicos humanos, buscando reconstituir a performance e teatro público apresentados pelos indígenas no Museu Nacional, enfatizando as repercussões populares dessa exposição. A intenção principal é descrever o que se passou com os indígenas, seus sentimentos, memórias e subjetividades, apesar de nem sempre os documentos históricos possibilitarem uma reflexão sob a posição das pessoas expostas.

Este trabalho encontra afinidade nas reflexões de Silva (2016), que, ao tratar da história de indígenas no Rio de Janeiro ao longo do século XIX, descreve a passagem dos Botocudos no Museu Nacional sob uma nova perspectiva, justamente porque a autora em questão preocupa-se com os sujeitos expostos, e não com a dimensão institucional da exposição. Há que destacar ainda o recente trabalho de Agostinho (2017), que pensa a exposição a partir da circulação de

8 Ver, por exemplo, a breve citação a essa exposição em Schwarcz (1993), quando trata da formação dos museus etnográficos brasileiros e dos "homens de sciencia". Schwarcz e Dantas (2008) analisam as coleções de Dom Pedro II, abarcando e citando dados sobre a Exposição Antropológica Brasileira, principalmente no que concerne à participação do imperador e cessão de sua coleção nessa exposição. Borges e Botelho (2012) analisam as imagens pintadas a óleo e expostas no Museu Nacional durante a Exposição Antropológica Brasileira, tendo como pano de fundo o desenvolvimento do positivismo nas artes. Nascimento (2009) analisa a formação da coleção de indústria humana do Museu Nacional, investigando as relações entre pesquisa e a formação do acervo, compreendendo a supracitada exposição como forma de divulgação do discurso científico dessa instituição. Andermann (2004) faz uma interessante análise da exposição enquanto um espetáculo da ciência, discutindo as representações visuais de objetos, bem como dos indígenas presentes na exposição em pintura, escultura, fotografia e caricatura. Dantas (2012) destaca a participação do Museu Nacional na Exposição Universal Internacional de 1889 em Paris, tomando a Exposição Antropológica Brasileira de 1882 como uma espécie de preparatório para a participação brasileira no evento francês. Rankel (2007) aborda a participação do Museu Paranaense na exposição de 1882 do Museu Nacional, enfatizando as relações entre discursos racialistas, formação de acervos e a construção de um discurso nacional. Para uma melhor compreensão da exposição a partir da questão da discussão sobre "raça" no pensamento indigenista do século XIX, ver Monteiro (1996). Para uma compreensão do processo de institucionalização da antropologia no Museu Nacional do Rio de Janeiro, ver Keuller (2008). 
objetos e pessoas, enfatizando a "exibição humana" e os exames de antropologia física a que os índios foram submetidos.

Adiante veremos algumas das particularidades da Exposição Antropológica Brasileira. Mas antes de chegarmos à exposição, vamos aos seus preparativos. Por que Botocudos, e como eles foram levados ao Rio de Janeiro?

\section{Os preparativos da "festa da sciencia"}

No dia 10 de setembro de 1881, Ladislau Netto, então diretor do Museu Nacional, escreve ao ministro da Agricultura para a publicação de uma circular com chamada à contribuição pública com a exposição, culminando em um documento emitido pelo Ministério da Agricultura, datado de 12 de outubro de 1881, publicado em diversos jornais de todo o país. Os interessados poderiam enviar desde vocabulários e lendas indígenas a esqueletos, múmias, colares ou objetos de argila, caça e pesca. Tal como descrito na circular, as contribuições estariam separadas entre as seções de antropologia, arqueologia e etnologia, havendo o comprometimento do museu de devolver os objetos ou arquivá-los com o nome do concessor (em caso de doação), formando-se um júri para premiar os objetos enviados.

A partir da referida circular, cartas e objetos foram remetidos ao Museu Nacional, com contribuições de uma série de províncias. Dentre estas chama a atenção o ofício ${ }^{9}$ escrito de próprio punho pelo presidente da província do Espírito Santo, Herculano Marcos Inglez de Souza, endereçado a Ladislau Netto, afirmando que embora não pudesse satisfazer os pedidos que foram feitos com relação à Exposição Antropológica, envia uma "familia" de sete pessoas "indigenas do Rio Dôce", acompanhados de intérprete, que darão "aos vizitantes da exposição uma idéa exacta de que são os indios do Rio Dôce". A "familia" é "composta d'um velho, casado com duas raparigas, uma velha, um rapaz e dois meninos de diversas idades". Acrescenta ainda que as duas mulheres têm "o tradicional botoque" e que eles "cantam e dançam de modo muito curis [ilegível] e tocam gaita pelo nariz". Inglez de Souza

9 Ofício de Inglez de Souza. Museu Nacional, Seção de Memória e Arquivo (Semear). Pasta 21, Documento 121. 
recomenda que, durante a sua estada, os tratem bem e deem-lhes presentes a fim de "entretel-os na idéa", uma vez que "os meus botocudos [...] vão ficar furiosos commigo, porq. lhes fis suppor que o vapor os levava para o Rio Dôce". Enganados, eles seguem para o Rio de Janeiro, chegando à corte no dia 6 de julho de 1882. Segundo relatório publicado na Assembleia Legislativa da província do Espírito Santo, do mesmo ano, "os indigenas regressarão a esta Provincia logo que sua presença foi desnecessaria na exposição" (Relatorio..., 1882, p. 38). No entanto, a viagem para alguns desses homens e mulheres se tornaria mais longa.

O presidente da província do Espírito Santo havia incumbido o engenheiro João Cassiano de Castro Menezes de coletar objetos com o intuito de representar a província na Exposição Antropológica. Acompanhado do fotógrafo Joaquim Ayres, eles foram os responsáveis por enviar o grupo de Botocudos, o intérprete do aldeamento do Mutum, Tertuliano Rodrigues do Carmo, e quatro caixões com objetos para a corte no Rio de Janeiro. Houve o interesse pela escolha de pessoas capazes de performar cantos e danças, seguindo a fórmula dos zoológicos humanos apresentados na Europa e sua preferência por famílias com crianças. Há ainda a ênfase no elemento exótico: "o tradicional botoque". Pela carta enviada por Inglez de Souza, fica claro que algo em especial foi pedido ao presidente da província do Espírito Santo, algo que não estava na chamada pública e geral publicada em setembro de 1881 . O diretor do Museu Nacional teria pedido expressamente por índios botocudos, ou simplesmente o engenheiro encarregado de coletar objetos resolveu fazê-lo? Note-se que o envio de índios (vivos) não é mencionado na chamada pública feita às províncias.

Segundo o Jornal do Commercio de 2 de julho de 1882, a "família de sete botocudos" pertenceria à etnia Nak-Nanuk, "como elles se denominão". Ainda segundo tal fonte, Ladislau Netto "os havia pedido" ao presidente da província do Espírito Santo "em numero de vinte", mas Inglez de Souza "teve de lutar com grande difficuldade para lhe enviar estes [índios] que acabão de chegar" (Jornal do Commercio, 1882a, p. 1).

Os índios botocudos desempenhavam um papel central no pensamento indigenista da época, figuravam como representantes dos Tapuia, apresentados como selvagens, bárbaros, grotescos e estúpidos, de tronco linguístico distinto do Tupi-Guarani. O antagonismo entre os Tupi e Tapuia ocorreu desde 
o processo de colonização e catequese, sendo os Tupi ${ }^{10}$ descritos como dóceis à colonização portuguesa. Partindo da distinção entre bons e maus selvagens, compreende-se o frenesi causado pela presença de índios considerados "bravios" na corte. Os Botocudos, além de muitas vezes citados como antropófagos, eram ainda mais importantes para a antropologia física ${ }^{11}$ praticada no Museu Nacional nas últimas décadas do século XIX. Em um momento em que se procurava o "elo perdido" entre homem e macaco, os pesquisadores do museu afirmavam que os Botocudos seriam o grupo primitivo mais inferior na escala evolutiva. Se pesquisadores de várias partes do mundo tendiam a afirmar que os pigmeus seriam o elo perdido, segundo o Museu Nacional ele estaria no Brasil! Esta é uma das razões por que houve repercussão internacional sobre a Exposição Antropológica Brasileira de 1882.

Joaquim Ayres, fotógrafo da expedição ao Rio Doce, encarregado de fotografar e remeter objetos e Botocudos à corte, relata em sua árdua expedição as dificuldades em trazer os índios, que teriam por diversas vezes fugido.

[...] levámos 27 dias nesta espinhosa arriscada viagem, trazendo 7 botocudos, sendo 3 mulheres e 4 homens, das mulheres 2 tem taboas no beiço, duas são moças e uma velha, dos homens um é velho, feio e desconfiado, dois são moços e uma criança de oito annos, grande quantidade de artefactos de uzo delles, tres ossadas completas, fazendo nós a exhumação, com grande risco de vida nas florestas do Rio-Dôce do lado Norte, um craneo e trez ossos do selvagem que assassinou o interprete de Fr. Bento de Bubbio e finalmente uma colecção de photographias constando de 18 retractos em cartões imperiaes e 16 vistas em ponto grande de objectos que dizem respeito a vida selvagem. [...] Das ossadas, também fui eu com

10 Um grupo de quatro índios xerente, da província de Goiás, havia chegado ao Rio de Janeiro em dezembro de 1881, vindos de uma longa jornada a pé, com o intuito de solicitar audiência com o ministro da Justiça e reclamar providências contra as violências que vinham sofrendo em suas terras. Comandados pelo cacique Casiva, esse grupo de três homens e uma mulher foi estudado pelos cientistas do Museu Nacional, tendo suas medidas antropométricas retiradas, cantigas e vocabulários registrados, além de moldes corporais para a confecção de manequins, esculpidos por Jean Baptiste Després e expostos durante a Exposição Antropológica Brasileira. O grupo em questão foi enfatizado como representante do tronco Tupi, em oposição aos Botocudos.

11 Segundo Sá et al. (2008), o médico e antropólogo João Batista de Lacerda foi responsável pelas primeiras atividades regulares de pesquisa e ensino da antropologia física no Museu Nacional, a partir do ano de 1872 . 
o Sr. Cassiano e os nossos dois camaradas que fizemos a exhumação; os botocudos que vierão, quem os convenceu a isso fui eu com o Sr. Cassiano, prometendo-lhes tudo, [...] não sendo muito facil convencel-os a virem, porque duas vezes nos fugirão e a terceira vez, é que podemos trazel-os. (Ayres, 1882). ${ }^{12}$

Ao chegar em Vitória os índios foram enganados sobre o destino do paquete Ceará, no qual embarcaram com destino ao Rio de Janeiro, acreditando que retornavam ao Rio Doce. Logo, não é muito de se estranhar que não estivessem satisfeitos em serem expostos no Museu Nacional, muitas vezes recusando-se a isso, como relatado em diversos jornais, que, entretanto, empenhavam-se em eufemizar em seus artigos o desconforto dos sujeitos expostos, ressaltando a importância da exposição.
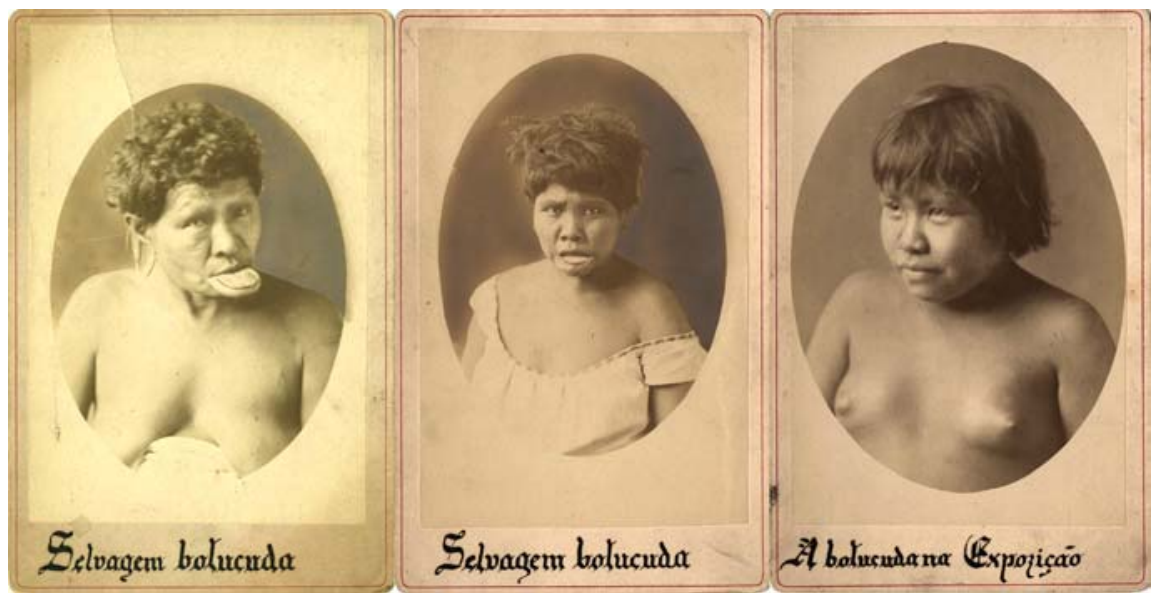

Figura 1. Fotografias das três mulheres expostas na Exposição Antropológica Brasileira de 1882, de autoria de Joaquim Ayres (fonte: catálogo on-line do Museu Etnográfico de Berlim). Estas fotografias foram expostas na sala Lund (ver Guia..., 1882).

12 Carta pública ao diretor do Museu Nacional em 31 de julho de 1882, publicada no jornal O Espirito-Santense, de 3 de agosto de 1882. 
Os Botocudos chegam ao Rio de Janeiro no dia 6 de julho de 1882, cerca de três semanas antes da inauguração da exposição. Queixavam-se de terem sido iludidos, ainda assim foram submetidos a estudos antropométricos, dirigidos pelo pesquisador do Museu Nacional, João Batista Lacerda - através de descrições morfológicas, características cranianas e medição de ossos e arcadas dentárias. ${ }^{13}$

Já estão, ha dous dias, nesta côrte os sete botocudos esperados da província do Espirito-Santo. Constam de 3 homens, 3 mulheres e 1 menino de 8 a 9 annos de idade. $O$ mais velho dos homens deve ter cerca de 60 annos de idade, é o typo perfeito do botocudo, cara larga, angulosa e repulsiva. Tem as orelhas furadas, mas não o labio inferior, como as duas mais velhas das mulheres, que usam de enormes botoques. [...] Estes indios nada fallam do portuguez. Mostram a maior indifferença pelo aspecto desta cidade e ao contrario estão desejosos de regressar quanto antes para suas selvas, queixando-se de que os illudiram, pois não contavam vir ter aqui. O Sr. director do museu, porém, conta que em poucos dias se acharão satisfeitos com os presentes que lhes está já fazendo e com o trazel-os em contacto constante com os objectos fabricados pela mesma tribu. Hontem passaram elles algumas horas no museu a tocarem flauta (pelo nariz) $\mathrm{e}$ a experimentarem-se ao arco e á flecha. E, na verdade, homens e mulheres pareciam esquecidos da sua nostalgia. (O Despertador, 1882a, p. 3).

Em decorrência dos preparativos da exposição, o Museu Nacional encontrava-se fechado para visitas, desde o dia 15 de maio daquele ano. Mas apesar disso, a chegada dos Botocudos causou comoção popular, fazendo com que fossem perseguidos pela população nos jardins do Campo de Santana, parque localizado à frente do Museu e espaço no qual instalaram o acampamento dos índios. Nas imediações do museu "estaciona uma onda de povo a espera dos pobres selvagens para recebel-os com umas provas de equivoca admiração" (Gazeta de Noticias, 1882a, p. 1), por isso os índios foram retirados do Campo

13 Para mais informações sobre os estudos antropométricos desenvolvidos nesta instituição, ver Sá et al. (2008). No ano de 1882, a pressão dos abolicionistas da escravatura aumentava, e então uma das questões investigadas pelos pesquisadores foi a força braçal dos Botocudos, com o intuito de usá-los como substitutos dos escravos negros (Andermann, 2004). 
de Santana, que à época era um dos espaços centrais da vida urbana do Rio de Janeiro, parque público adjacente à estação central de trens, e levados para o palácio de São Cristóvão, junto ao imperador Dom Pedro II. Desta forma lamenta o jornal Gazeta de Noticias (1882a, p. 1): “É pena porém que uma parte do público não tenha querido comprehender o espirito de caridade que devemos ter para os pobres indios botocudos que de bom grado se prestam aos estudos a que os sujeitam no Muzeu."

Desde os primeiros dias da estada dos Botocudos na corte, o diretor do museu precisou lidar com a perseguição do público. Durante a sua estada em Vitória, os índios já haviam despertado a atenção da população, sendo seguidos por "uma turba de curiosos" (A Provincia do Espirito-Santo, 1882, p. 3). A tensão entre público, índios e o museu transparece nos relatos de jornais desde o primeiro momento, havendo um crescendo com o passar do tempo, o que levou o museu a tentar remediar a questão: o interesse do público seria algo esperado e desejado, mas a instituição, por outro lado, toma medidas para resguardar os índios do assédio do público e ao mesmo tempo tenta "educar" a audiência, usando os jornais para moldar a maneira como os visitantes deveriam se comportar.

No dia 20 de julho, cerca de dez dias antes do início da exposição, foi comunicado por meio de jornais que os Botocudos seriam expostos no quartel do corpo de bombeiros, edifício vizinho ao Museu Nacional, tendo sido o diretor do museu "obrigado a tomar esta medida" como forma de "conciliar as exigencias do publico" e sua "ardente curiosidade" e ao mesmo tempo deixar os índios mais tranquilos para "percorrerem os salões da exposição anthropologica e dançar e cantar á sua vontade, sem os empurrões de que foram elles victimas" (Gazeta de Noticias, 1882b, p. 1). Uma quantia de 500 réis seria cobrada para ver os Botocudos, argumentando-se que o dinheiro seria dividido entre o intérprete e os índios "como um forte argumento que os obrigará a ficar mais algum tempo em proveito da festa para que aqui vieram" (Gazeta de Noticias, 1882b, p. 1).

\section{A Exposição Antropológica Brasileira}

A cerimônia de inauguração da Exposição Antropológica Brasileira contou com a presença das majestades imperiais e discurso de Ladislau Netto, diretor do 
Museu Nacional. Mas apesar das oito salas ${ }^{14}$ do museu terem encantado seus visitantes, o momento mais esperado seria a exibição dos Botocudos trazidos do aldeamento do Mutum, que, entretanto, não estavam presentes.

Em crônica assinada por Júlio D., na Revista Illustrada (1882a, p. 2), o autor afirma que visitou a exposição apenas no seu segundo dia, 30 de julho, justamente para evitar "a amolação" dos "discursos analogos ao acto", em que há uma mania "de nossos eloquentes, que se aproveitam de cada festa para nos repetirem todos os logares communs que lhes passam pelas cabeças". Essa crônica relata que o museu foi tomado de assalto pelo público, fazendo com que o diretor Ladislau Netto quase tivesse que "recorrer ás bayonetas" diante da "selvageria fluminense".

Tanto interesse pela sciencia espanta-me; mas eu acabo por verificar que toda essa curiosidade dos visitantes é apenas para ver os indios. Com effeito, apenas entrados, percorrem, olham, caçam... Nada de indios, além de alguns de papelão, que não satisfazem totalmente a cubiça publica.

Reclamações, protestos, movimento já de partida... Um gaiato lembra-se de espalhar que os indios estão escondidos nos aposentos do director do Museu; e eis os aposentos do Dr. Ladislau Netto invadidos até á cosinha.

Procuram, caçam, varejam toda a casa... Os pobres indios, coitados, corridos da

14 Essas salas foram nomeadas em homenagem a pesquisadores e viajantes que contribuíram com a antropologia brasileira e estudos indigenistas. A primeira das salas com a qual se deparava o visitante era a Vaz de Caminha, com arcos, flechas e remos expostos em vitrines. "No vestibulo e aos lados da escadaria que conduz á primeira sala" viam-se "primorosos arbustos e elegantes coqueiros, dispostos artisticamente" (Diario de Pernambuco, 1882, p. 2). Na sala seguinte, José de Anchieta, encontravam-se pinturas, desenhos e litografias de diversas tribos, além de edições de livros raros de estudos etnolinguísticos e etnográficos indigenistas. A maior das salas era a terceira, Rodrigues Ferreira, no centro da qual foram representadas as margens de um rio, com manequins de índios, canoas, arcos e flechas pendendo do teto. A sala seguinte, nomeada João de Lery, guardava objetos arqueológicos provenientes do Amazonas e sambaquis do sul. Em seguida estava a sala Hart, com objetos de cerâmica. A sala Martins dispunha de diversos artefatos, da coleção privada de Dom Pedro II a produtos cerâmicos do Peru, Guiana Holandesa, Amazonas e Paraná. Na sala Gabriel Soares estavam vestimentas de diversas tribos, bem como instrumentos de guerra, caça e pesca de índios do Pará. A última sala, denominada Lund, guardava ossos de sambaquis e esqueletos e crânios dos Tembé e Botocudos, além de fotografias destes últimos (ver Guia..., 1882). 
selvageria fluminense, ha muito, já se tinham ido refugiar em São Christovão, junto ao grande cacique..$^{15}$ (Revista Illustrada, 1882a, p. 2).

Cinco dias após a sua inauguração, Dom Pedro II visita novamente a exposição, ocasião em que os Botocudos "achavam-se no museu prestando-se aos trabalhos de que são assumpto seus caracteres physicos" (Gazeta de Noticias, 1882c, p. 1). Noticia-se que dentro de alguns dias os índios seriam expostos no quartel do corpo de bombeiros. Mas no domingo seguinte eles são levados para a Quinta da Boa Vista, alegando-se que no quartel não haveria espaço suficiente, o que impossibilitaria o uso do local em caso de incêndio. Ladislau Netto "attendendo á curiosidade pública" teria providenciado "para que os botocudos possam ser vistos hoje mesmo [domingo, 6 de agosto de 1882] na quinta de S. Christovão, das 11 horas da manhã ás 2 da tarde", completando o anúncio que "se d’essa primeira exposição nenhum inconveniente resultar da parte dos curiosos, é provavel que outras exposições iguaes se lhe succedam, como meio de satisfazer a curiosidade dos que não os tiverem visto amanhã" (Gazeta de Noticias, 1882d, p. 1).

Um mês após a sua inauguração a exposição continuava a ser bastante visitada, "fallando todos os visitantes com satisfação do que veem e observão" (A Patria, 1882, p. 3). Um cronista chega a descrever ter havido mais de três mil visitantes em um só domingo, reclamando inclusive do grande afluxo e do comportamento do público.

A exposição anthropologica chama todos os dias aos salões do museu um numero consideravel de curiosos e um pequeno numero de pessoas que alli vão estudar. O nosso povo dá a vida por uma exposição... quando a entrada é gratuita.

Tive por varias vezes occasião de ir á exposição da industria nacional e fazer um calculo do numero de pessoas que lá iam, em relação ao preço de entrada. Nos dias de $1 \$ 000$ encontravam-se 50 a 60 pessoas; nos dias de 500 réis, 200 a 300 e nos de 200 réis, 2,000 e mais.

Quer isto dizer que o povo gosta de ver cousas bonitas por preço diminuto.

Na do museu não se paga. O cidadão entra alli como em casa, de chapeu na cabeça e sem receiar que os porteiros o encommodem.

15 O "grande cacique" é a referência jocosa da época ao imperador Dom Pedro II. 
No domingo havia nesta exposição mais de 3,000 pessoas entre as que percorriam os salões e as que estavam ás portas do edifício esperando a sua vez.

É uma bonita exposição, deficiente, é verdade, mas cheia de attractivos. O homem de sciencia tem alli campo vasto para estudos, mas é necessario que se estabeleça uma esportula á entrada, afim de ver se vai lá menos gente.

No meio de tanto povo não se póde estudar. (Echo do Povo, 1882, p. 1).

Ironicamente, um dos problemas da exposição foi o seu grande sucesso, não apenas para o autor do relato acima, que demanda uma cobrança em dinheiro como forma de restringir o acesso do "povo", bem como para o próprio museu, que por várias vezes foi aos jornais, na figura de Ladislau Netto, reclamar do comportamento do público, ameaçando retirar os índios botocudos da exposição, em uma espécie de negociação com o espectador, avisando que os índios continuariam a ser expostos "se [...] nenhum inconveniente resultar da parte dos curiosos". Os inconvenientes não se restringiam ao espaço do museu e ao incômodo causado aos índios. A Revista Illustrada (1882b, p. 2), do jornalista e cartunista Angelo Agostini, relata que na quinta-feira, 10 de agosto de 1882, bateu um senhor à porta da casa do diretor do Museu Nacional, às 11h30 da noite, pedindo que a criada da casa o chamasse, para tratar de "um negocio importantissimo" e "urgente", dizendo o homem a Ladislau Netto: "Queria pedir-lhe um favor: parto amanhan para São Paulo pelo trem das seis, e não queria ir, sem ter visto os botocudos!"

\section{Devorados pela curiosidade pública}

A Revista Illustrada (1882a) traz uma ilustração sequencial publicada em duas páginas, sobre a Exposição Antropológica. O primeiro quadro mostra Dom Pedro II de costas, na presença de Ladislau Netto, olhando estátuas sobre uma mesa (ver Figura 2). Escondido por detrás de uma cortina está o arlequim, personagem criado por Agostini e presente em várias ilustrações do jornal. O narrador conta: "Graças a um amavel convite do director do Museu, conseguimos entrar na exposição anthropologica, e lá deparamos com S. M. apreciando os idolos e manipanços de seus mais legitimos subditos" (Revista Illustrada, 1882a, p. 4). 

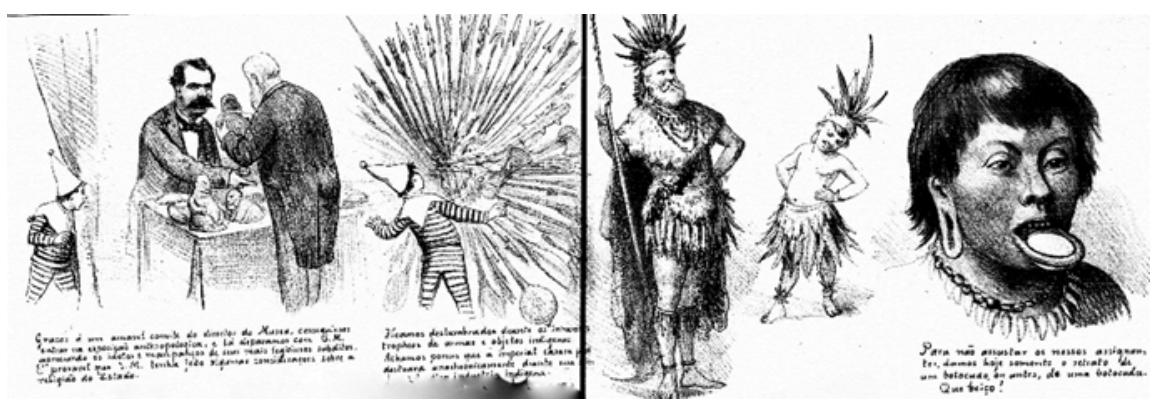

Figura 2. Revista Illustrada (1882a, p. 4-5). Da esquerda para a direita veem-se os quadros 1, 2, 3 e 4 .

O segundo quadro mostra o arlequim admirado com várias flechas, remos e outros adereços, que colocados em arranjo, uns sobre os outros, parecem explodir sobre o espectador. O narrador conta: "Ficamos deslumbrados diante os innumeros tropheos de armas e objetos indigenas. Achamos porem que a imperial casaca [ilegível] destoava anachronicamente diante essa artística e selvatica industria indigena" (Revista Illustrada, 1882a, p. 4). O terceiro quadro mostra Dom Pedro II em pose afeminada, com a mão esquerda na cintura, cocar na cabeça, colares, pulseiras e adereços na perna, segurando uma lança com a mão direita. Dom Pedro mantém o olhar altivo, enquanto o arlequim, igualmente vestido de índio, o olha de cima para baixo em deboche (ver Figura 2). Continua o narrador: "Parece-nos que se o nosso imperial senhor juntasse ao seu imperial costume de papos de tucanos ${ }^{16}$ mais algumas pennas, daria com certeza um imperial cacique bem bonito" (Revista Illustrada, 1882a, p. 5). A ilustração de Agostini faz paródia direta ao famoso quadro de Pedro Américo, A fala do trono, de 1873. Em Agostini temos praticamente a mesma pose de corpo inteiro, no entanto o imperador, ornado com seu manto imperial e adereços indígenas, metaforicamente "está nu". O quarto quadro mostra o rosto de uma índia de olhar impassível, orelhas alargadas,

16 Para mais informações sobre como a coroa, o cetro e a murça feitas de papos de tucanos usadas pelo imperador davam feições tropicais e elementos tupi-guarani ao Segundo Império, ver Schwarcz (1998). 
batoque e colar de dentes. Explica o narrador que: "Para não assustar os nossos assignantes, damos hoje somente o retrato de um botocudo, ou antes, de uma botocuda. Que beiço!" (Revista Illustrada, 1882a, p. 5).

O quinto quadro mostra um casal de Botocudos, agachados, tentando se beijar. Sobre eles paira um cupido (ver Figura 3). O homem veste uma tanga, enquanto a mulher está de peito desnudo. O narrador postula: "Imaginem dois botocudos namorando-se e dando-se beijos! Que idyllio!!" (Revista Illustrada, 1882a, p. 4) (em outras publicações da mesma revista já havia surgido o questionamento irônico, sobre como fariam os Botocudos para se beijar). O sexto quadro mostra um Botocudo de feições animalescas, dentes afiados e orelhas alargadas, tentando devorar o arlequim do jornal. Nessa representação o Botocudo é um gigante que coloca em sua boca um pequeno ser indefeso. O narrador pontua: "Mas tambem quando a gente se lembra que elles assentam um pobre christão naquelle prato que trazem no beiço e o engolem como se fosse feijoada!... Que horror!" (Revista Illustrada, 1882a, p. 4-5). O sétimo e último quadro mostra Ladislau Netto segurando pelo botoque um índio assustado, que tenta fugir. Enquanto isso um público arruaceiro e debochado empilha-se ao fundo, no esquadro de uma porta, tentado passar para o primeiro plano e adentrar a sala em que a primeira ação ocorre. O narrador afirma: "Mas quem diria! Esses anthropophagos é que ficaram com medo de serem devorados pela curiosidade publica. Só á muito custo o director do Museu impediu que elles fugissem" (Revista Illustrada, 1882a, p. 5)

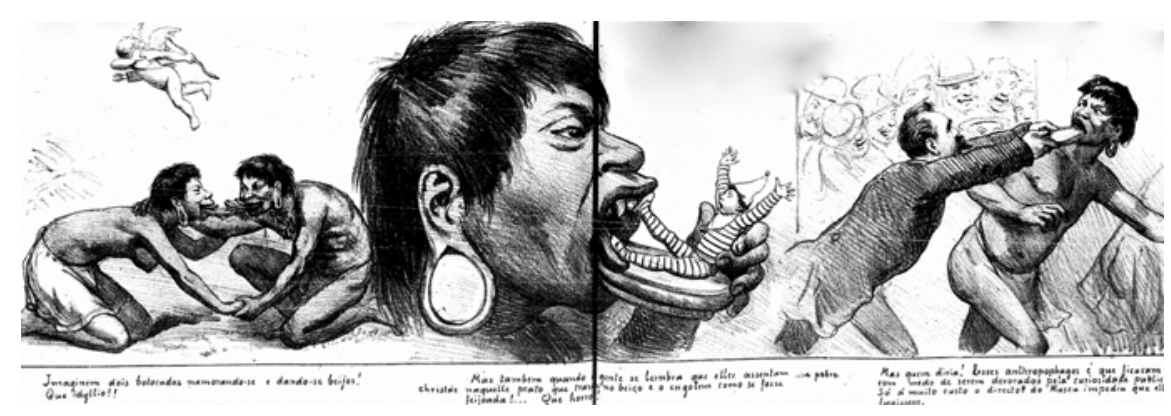

Figura 3. Revista Illustrada (1882a, p. 4-5). Da esquerda para a direita veem-se os quadros 5,6 e 7 . 
Agostini faz sua leitura crítica do evento tão divulgado pelos jornais nacionais e concorrido entre os cidadãos da corte. Antes de tudo, ele tem como objetivo, enquanto um abolicionista republicano, ironizar a figura de Dom Pedro II, o que ele faz não apenas nessa edição da Revista Illustrada. A narrativa sequencial em imagem e texto, descrita acima, demonstra como em apenas duas páginas os sentimentos sobre os índios botocudos pendulam entre interesse, fascínio e pena, para medo e repulsa. Nos quadros 1 e 2, há a demonstração de interesse por seus objetos artísticos. Nos quadros 4 e 5 , há a amabilidade e sexualização do corpo indígena feminino. No entanto, o próprio quadro 5 aponta ironicamente para impossibilidade de os Botocudos poderem se beijar, talvez mesmo se amar de forma apropriada, segundo os padrões do cupido e do narrador. $O$ quadro 6 aponta a bestialidade da representação antropofágica dos Botocudos, lembrando ao leitor que apesar de todo o interesse que eles possam despertar, são perigosos. Por fim, o sétimo quadro apresenta algumas das violências a que os índios foram submetidos, tanto por parte do museu quanto por parte do público, invertendo a questão e apresentando os perigos que eles sofreram na Exposição Antropológica, em que os temidos canibais quase foram "devorados pela curiosidade pública".

A noção de curiosidade é recorrente em diversos jornais, que usam o termo tanto para designar os índios enquanto curiosidades quanto para apontar a "curiosidade ardente" dos visitantes, muitas vezes descrevendo o público como uma multidão de curiosos, diferenciando-os do "homem de ciência". O termo curiosidade carrega uma ambiguidade. Na língua portuguesa a palavra pode ser definida tanto por um intenso desejo de conhecer quanto pela indiscrição e bisbilhotice. ${ }^{17} \mathrm{~A}$ curiosidade dos visitantes muitas vezes resultou em inconvenientes, assim como os Botocudos despertavam a curiosidade porque eram insólitos, exóticos em seus batoques, costumes e traços físicos, até mesmo descritos como feios e repugnantes. Essa dimensão ambígua está presente nas descrições dos jornais.

17 Segundo o Dicionário Houaiss da Língua Portuguesa: "desejo intenso de ver, ouvir, conhecer, experimentar alguma coisa nova, original, pouco conhecida ou da qual nada se conhece"; "interesse, procura de coisas originais, insólitas"; "desejo irrequieto, frequentemente malévolo, de se inteirar de segredos e particularidades da vida alheia; indiscrição, bisbilhotice”. 
Na obra Confissões, escrita entre os anos de 397 a 400, Santo Agostinho (1999) discursa sobre a curiosidade ou curiositas, considerada como uma das primeiras conceitualizações sobre o interesse em performances de monstruosidades e estranhezas que durante a idade média e século XVI levou multidões a feiras locais, representando o prazer de ver apesar, ou justamente por conta, da ruptura com os padrões canônicos de beleza (Kolos, 2014). Em Santo Agostinho a curiosidade seria uma espécie de tentação pérfida que deveria ser evitada, como uma forma de pecado, assim como qualquer desejo de conhecer apenas por conhecer. Santo Agostinho considera que os sentidos podem enganar a razão e que, dentre eles, a visão seria o sentido preponderante e naturalmente dado ao conhecer. Para este autor, a curiosidade pode ser compreendida tanto como um prazer por coisas belas quanto como uma atração por coisas repulsivas e desagradáveis, como observar um cadáver.

Partindo da ambiguidade do uso do termo curiosidade, podem-se compreender melhor as formas de representação dos Botocudos na Exposição Antropológica Brasileira, bem como o prazer ambivalente em vê-los, por parte dos espectadores e tal qual descrito nos jornais, de simultânea repulsa e atração por tais índios.

O estado de espírito dos Botocudos era de óbvio descontentamento. A publicação satírica Revista Illustrada aproveita o ensejo para fazer piada. Conta que os índios queriam ir embora, apesar de todos os cuidados com que os tinha cercado o grande capitão, Dom Pedro II: “[...] ao que parece, vendo-se tão bem tratados, receiam, segundo as suas ideias, estar sendo engordados para serem depois comidos" (Revista Illustrada, 1882b, p. 3). A mesma revista, em edição posterior, comenta que os Botocudos têm "emagrecido a olhos vistos", apesar de estarem cercados de cuidados "no palocio do 'grande capitão', já que "o menú do paço [...] não lhes apraz ao appetite"; por fim ironiza que "tambem, não lhe deram ainda nem uma coxinha de gente!" (Revista Illustrada, 1882c, p. 3, grifo no original). A Revista Illustrada enfatiza em suas ilustrações e comentários sobre a Exposição Antropológica, a imagem dos Botocudos como antropófagos. Nessa mesma edição, Angelo Agostini publica uma ilustração com dois índios botocudos, magros de fome, mordendo Dom Pedro II (ver Figura 4). A legenda diz o seguinte: "Consta-nos que os botocudos que se acham hospedados na Quinta de S. Christovão, estão emmagrecendo muito. Se esses canibaes se lembram de querer almoçar o nosso imperador!... Verdade é que ja temos outro de reserva nos Estados-Unidos..." (Revista Illustrada, 1882c, p. 8). 


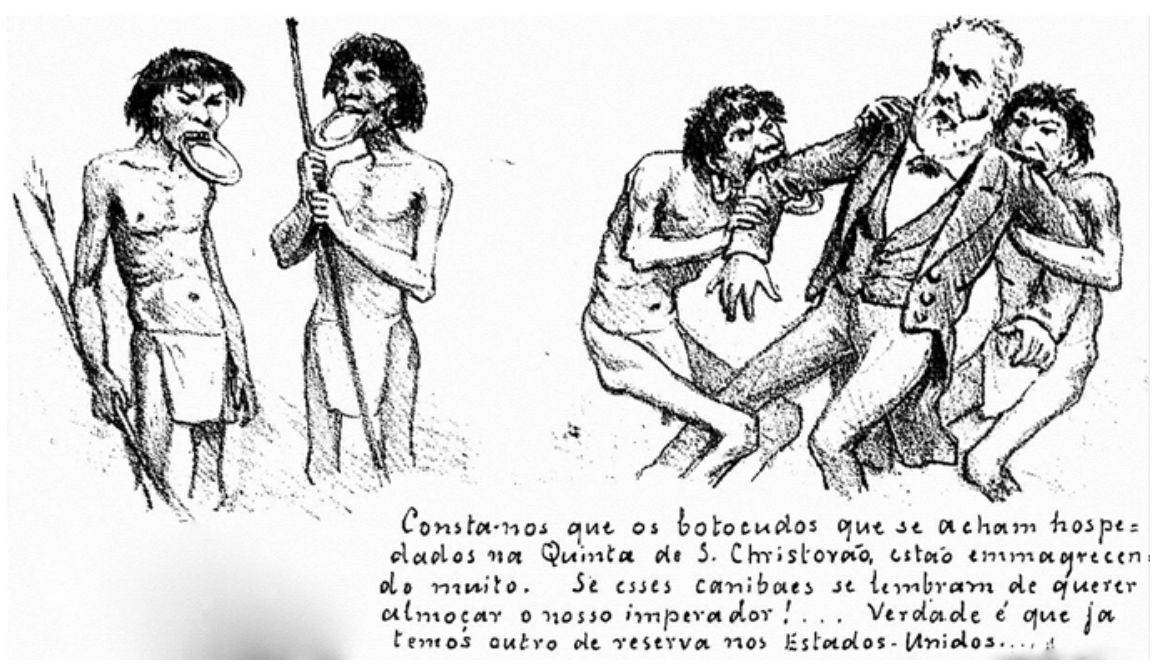

Figura 4. Revista Illustrada (1882c, p. 8).

Apesar de retratados como canibais, feios, hediondos e selvagens, os Botocudos foram a atração principal daquele primeiro mês da Exposição Antropológica do Museu Nacional, conseguindo inspirar casos de amor, verdadeiros e ficcionais. Na coluna "Recadinhos", do jornal O Mequetrefe (1882, p. 7, grifo no original), há um convite/recado apaixonado, publicado no dia 20 de agosto:

\section{MEU AMOR}

Domingo vou a exposição antropologica e espero que tu lá estejes. Não tenhas medo dos botocudos. Elles têm os beiços de baixo maiores do que os de riba, mas não comem ninguem.

Vae que eu te espero ao pé dos movitos engarrafados.

Teu do coração

Juca Peçanha.

A Exposição Antropológica teve tamanho sucesso, que chegou a inspirar uma comédia, intitulada Os botocudos, escrita e dirigida pelo Dr. Moreira Sampaio, que estreou nos palcos do teatro Recreio Dramático, no Rio de Janeiro, no dia 25 de outubro. A peça trata do casal, formado pelo comendador Pancracio e sua esposa Amélia, e da visita que fazem à exposição do Museu Nacional, após as 
insistências e pedidos da esposa, apesar do horror que o marido sentia pelos "canibais botocudos". Chegando ao museu, o comendador assusta-se ao ver os índios que entram em cena correndo de uma sala a outra. Nesse momento é roubada a carteira de um dos visitantes, distraído a olhar algumas flechas. Forma-se uma confusão e Pancracio perde-se de Amélia. O comendador desespera-se, acreditando que os Botocudos comeram a sua esposa, no entanto Amélia havia desmaiado nos braços de seu amante, recolhendo-se na casa dele. Segundo a crítica da Revista Illustrada (1882d, p. 6), apesar de demasiado longa, a peça "dá um bello espectaculo, alegre e divertido", destacando ainda os papéis de uma inglesa extremamente interessada pelos Botocudos e que a cada nova flecha ou objeto encontrado exclamava beautiful, em contraste com a indiferença de um major, furioso por ter pagado 200 réis pelo catálogo da exposição. Os casos de amor, sejam os ficcionais ou não, demonstram as multiplicidades de olhares e usos que os espectadores fizeram da exposição.

Em análise a essa exposição, Jens Andermann (2007) chega a se perguntar se de fato os índios xerente e botocudos teriam estado presentes no Museu Nacional, porque, de acordo com o autor, tudo o que nos resta são seus traços e indícios, representações de representações, que na verdade denotam as políticas museais da época, que converteram os corpos indígenas em simulacros de si mesmos, reduzindo-os a tipos raciais.

Considero que, se os documentos oficiais e as formas de mensuração da antropologia física apagam as dimensões do espetáculo, de acordo com os relatos de jornais, os Botocudos pareciam performar o mito do primeiro contato. ${ }^{18}$ Apesar de terem vivido no aldeamento do Mutum, portanto sob o jugo e tutela do Estado, foram lidos pelo habitantes da corte como se estivessem tendo seu primeiro contato com os brancos naquele momento, já que, segundo as fontes, performavam medo e fuga. Essa foi a performance e forma de interação principal entre índios e público, ao longo da Exposição Antropológica Brasileira. Até mesmo na peça de teatro de Moreira Sampaio eles são representados correndo de uma sala à outra. Apesar de terem dançado e cantado, a sua fuga, melancolia e relutância em se fazerem vistos inflamava o desejo dos espectadores em vê-los. Ou seja, a negação do espetáculo fez parte do espetáculo. A Revista

18 Mary Louise Pratt (1999) considera o mito do primeiro contato como um gênero literário que permeia a literatura etnográfica e os relatos de viajantes, um dos mitos fundantes da antropologia. 
Illustrada faz piada e chega a afirmar que os Botocudos "nunca eram encontrados" na exposição.

De maneira geral, os jornais da época enfatizavam a importância da Exposição Antropológica Brasileira, apesar de relatar como os Botocudos se sentiam descontentes de participarem dela. Por meio da imprensa, era sabido que os índios fugiam do público, eram perseguidos e empurrados, se sentiam "nostálgicos", emagreciam de fome, declaravam abertamente que queriam retornar ao Mutum, além de terem sido enganados para estar no Rio de Janeiro. Não havia pudor em relatar nenhuma dessas violências, sempre eufemizadas nas narrativas jornalísticas, em favor da "festa da ciência".

Os Botocudos retornam para o aldeamento do Mutum no dia 30 de agosto de 1882, embarcados no paquete Ceará, o mesmo que os trouxera. Assim eles realizam o desejo de Ladislau Netto, que era o de assegurar a permanência dos índios ao menos pelo primeiro mês da exposição, inaugurada no dia 29 de julho.

Quando da partida dos índios, ou quando eles não se faziam mais necessários à exposição, foi mais fácil para os jornais retratarem a insatisfação que tinham os Botocudos, sem ter que em seguida eufemizar o fato com a relevância científica da exposição. Na Gazeta de Noticias de $1^{\circ}$ de setembro de 1882, lê-se:

Os botocudos, que figuravam na Exposição Anthropologica, regressaram ante-hontem para o Espirito-Santo, no paquete nacional Ceará.

Acabrunhados pelas saudades dos logares onde têm passado toda a vida, manifestavam-se, n'estes ultimos dias, profundamente aborrecidos, solicitando com insistencia os meios de voltar áquella provincia. Estes desejos foram satisfeitos, e, á esta hora devem os botocudos estar em caminho dos lares.

Felicidades. (Gazeta de Noticias, 1882e, p. 2).

No entanto, as condições do aldeamento do Mutum não eram as mesmas desde a sua partida: "Para o aldeamento elles não irão, isto é sabido, porque o do Mutum só existe o nome e.... ruinas....", afirma O Espirito-Santense (1882, p. 2).

Ao todo, os índios ficaram na corte imperial por 56 dias, já que eles haviam chegado ao Rio de Janeiro no dia 6 de julho. No entanto, ficaram afastados de suas casas por pelo menos 70 dias, mas as suas dores foram amortizadas pelos jornais que descreviam a "caridade" que tais índios faziam diante da ciência. 
No dia 16 de novembro de 1882, o Diario do Brazil noticia o envio de cinco Botocudos para Londres, com escala no Havre, cidade portuária francesa. Algumas semanas depois se publica na Gazeta de Noticias o fato de que alguns desses Botocudos foram os mesmos que figuraram na Exposição Antropológica Brasileira. A partir daqui inicia-se uma nova história, com mudança de retórica, personagens e cenários. Os índios foram levados por uma empresa privada, registrada no nome da família Barata Ribeiro. A partir da mudança de escalas e perspectivas, os jornais nacionais passam a criticar o envio dos índios, iniciando uma campanha pública em prol de seu retorno, muitas vezes usando-se de argumentos jurídicos e humanitários para tal; no entanto o argumento mais comum era, de fato, que o Brasil não poderia ser representado "lá fora" por "silvícolas" botocudos, afinal, o que pensariam de nós na Europa?

\section{Enviados a Londres}

Quando da publicação de um telegrama enviado do Espírito Santo para a corte, que relatava a maneira sorrateira com que cinco Botocudos haviam sido embarcados em um navio europeu, vários jornais do Rio de Janeiro passam a tomar parte do fato, a maioria em um tom de indignação. O principal deles foi o jornal de oposição, Gazeta de Noticias, que investiga os pormenores desse embarque. A sua principal fonte de informações foi o jornal $O$ Espirito-Santense, editado por Bazilio Carvalho Daemon. Enquanto isso, a publicação situacionista, Jornal do Commercio, cede espaço para que os responsáveis pelo envio dos Botocudos defendam-se diante das acusações, abrindo-se um campo de batalhas em torno do que viria a ser conhecida como "a questão dos Botocudos".

Ao passo que a exposição do Museu Nacional foi um evento oficial organizado pelo Estado, a sua versão europeia foi promovida pelos irmãos Athanagildo e Cremilde Barata Ribeiro, empresários da indústria de estaleiros, ${ }^{19}$ que

19 Em maio de 1880, os irmãos e sócios Athanagildo e Cremilde obtiveram deferimento do pedido de abertura de matrícula como comerciantes da Barata Ribeiro \& C., registrando um estaleiro ou "negocio de construcções navaes, machinas e mais artigos concernentes ao serviço maritimo" (Gazeta de Noticias, 1880, p. 1). Apesar de parecer que o negócio do estaleiro ia bem, em outubro de 1881, tenente reformado da armada, Athanagildo Barata Ribeiro declara pública sua candidatura para deputado do $2^{\circ}$ distrito da corte, dizendo-se representante dos "industriais honestos e amantes do progresso"; ele, no entanto, perde a eleição. 
mantinham relações com o governo. ${ }^{20}$ Mas a família Barata Ribeiro estaria destinada a ter um outro membro de papel proeminente na política nacional, o médico e professor da Faculdade de Medicina da corte, Candido Barata Ribeiro, ${ }^{21}$ que viria a ter uma atuação polêmica como o primeiro prefeito do Distrito Federal, cidade do Rio de Janeiro, após a instauração da República.

Cremilde Barata Ribeiro era casado com Elizabeth Hughes, inglesa radicada no Rio de Janeiro, e que o acompanhara junto com os Botocudos na turnê pela Europa. Não há como precisar ao certo a origem da ideia de expor os índios em Londres, mas é possível que a família Barata Ribeiro, e especialmente a esposa, já estivesse acostumada a esse tipo de entretenimento, tendo em vista a longa tradição dessas formas de exibição na capital britânica. ${ }^{22}$ E o próprio Dom Pedro II? Personagem ativo na Exposição Antropológica do Museu Nacional, e com quem a família Barata Ribeiro tinha relações, teria ele sabido dos planos de Cremilde e Athanagildo?23 É certo que os irmãos Barata Ribeiro têm a intenção de repetir na Europa o sucesso e furor causado pelos Botocudos na corte brasileira, imitando em Londres não só o mesmo título e temática, como levando inclusive índios da mesma trupe que compunha a exposição do Museu Nacional. A exposição é inaugurada em Londres, no teatro popular Piccadilly Hall, em meados de maio de 1883. Mas até essa data a questão dos cincos Botocudos brasileiros enviados a Londres ganha os jornais, e é dela que nos ocupamos agora.

O telegrama publicado pelo Diario do Brazil revela que os índios teriam saído do aldeamento do Mutum acompanhados de três cavalheiros e uma dama. Hospedaram-se em Linhares, "ficando eles como que ocultos", seguindo no outro dia para Vitória. Dada a dimensão do "mistério" que segundo o informante se fez nesse embarque, conduzido fora da barra, em alto mar, e não no porto rotineiro, além do fato da emissão apressada dos passaportes para os indígenas, questiona-se:

20 Em 25 de outubro de 1881, a Gazeta de Noticias noticia o nome de Athanagildo entre as personalidades que haviam estado com as majestades imperiais na semana anterior.

21 Candido Barata Ribeiro foi responsável pela destruição do cortiço Cabeça de Porco no Rio de Janeiro, que marca o início das reformas urbanas e remoções de cortiços e favelas que caracterizam as décadas seguintes da então Capital Federal.

22 Ver Altick (1978).

23 A Gazeta de Noticias de 25 de Outubro de 1881 afirma que, dentre outras personalidades, o senhor Athanagildo Barata Ribeiro teria estado com as suas majestades imperiais. 
Como explicar a sahida dos aborigenes de um aldeamento? Houve licença? Como explicar a vinda extemporanea de um paquete, que aqui nunca veiu nem era esperado, ficando fóra da barra, e que aqui não tocou senão mediante muito dinheiro? Como embarcar indigenas para a Europa sem licença do governo, e especialmente não podendo o director do aldeamento deixal-os sahir.

Póde um simples particular dispôr assim da liberdade desses infelizes, que sem duvida vão enganados? Destes cinco indigenas, dous rapazes e tres mulheres, ha entre estas uma que já falla o portuguez, e vai servindo de interprete, a qual dizia que iam para o Rio de Janeiro para voltarem logo!...

As cautelas e prevenções tomadas por um desses cavalheiros, o mysterio em tudo isto deixa pensar muita cousa.

Agora. - Deu o governo geral permissão para seguirem esses filhos das selvas para a Europa? Será uma especulação, como qualquer outra para se ganhar dinheiro pela exposição dos mesmos? Póde-se dispor da liberdade dessas tristes creaturas, que lá vão sujeitar-se, sabe Deus como, a saciar o gosto de observação dos estrangeiros! Voltarão elles ao seu Aldeamento no Rio-Doce, ou morrerão, coitados, de nostalgia?

Pobre Brazil e pobre provincia do Espirito-Santo! Se até aqui passamos por macacos, se á pouco chegados da Europa estrangeiros, vieram persuadidos que esta provincia era sómente composta de tribus indigenas, por na côrte terem sidos expostos os botocudos na Exposição, que conceito farão de nós, quando nos theatros, talvez em exhibição forem apresentados os nossos incolas? Que somos todos botocudos [...]. E os pobres indios morrendo, porque a estação na Europa é fria, ainda seus ossos serão vendidos para estudos nas academias e em gabinetes particulares!... (Diario do Brazil, 1882b, p. 2, grifo no original).

É importante lembrar que essa verve humanitária começa a tomar forma a partir do momento em que os índios deixam a corte (no dia 30 de agosto), irrompendo nos corações e mentes da nação quando os índios são notadamente enviados para fora do Brasil, em meados de novembro de 1882. A maioria dos jornais que se posicionaram contrariamente ao envio dos índios brasileiros segue o mesmo mote argumentativo do artigo publicado acima, oscilando de argumentos jurídicos e humanitários à preocupação com a imagem do Brasil transmitida pelos índios no Velho Mundo. 
A Gazeta de Noticias (1882f, p. 1) afirma que o embarque "a todos pareceu repugnante, porquanto constava que o embarque dos botocudos fôra feito com o proposito de abrir-se uma exposição dos pobres indigenas na Europa". Os Botocudos deveriam "figurar aos olhos da civilisação do velho mundo, naturalmente mediante pagamento, como typos da raça aborigene d'este feliz imperio da Santa Cruz". Houve o pagamento de 7000 réis com o frete do paquete Ville de Bahia, que fez escala extraordinária em Vitória, e 1000 réis ao prático que orientou o vapor, não ao porto, mas a um embarque sorrateiro. A uma certa distância de Vitória, "o paquete fundeou em 18 metros d'agua, e recebeu a bordo os botocudos, tripolantes de uma canôa”. Assim partiu o Ville de Bahia, rumo à França, retornando a canoa com o prático e um companheiro de Cremilde Barata Ribeiro desse embarque atípico. Quando chegaram a "terra, tanto o pratico como o cavalheiro que o acompanhavam, encontraram o povo, indignado pelo facto que se passara, aggravado em sua natureza pela circumstacia de ter sido abandonada na praia uma india, muito enferma" (Gazeta de Noticias, 1882f, p. 1).

O companheiro de Cremilde era na verdade Athanagildo Barata, que ao chegar à corte empenha-se em responder as notícias divulgadas pela Gazeta de Noticias. É muito provavelmente este personagem quem assina inicialmente uma pequena carta pública, sob o pseudônimo de "Um brazileiro agradecido", em que afirma causar indignação a forma como os jornais da corte têm tratado da "formação da Companhia Industrial do Rio Doce. É sempre assim: as boas ideias encontrão logo opposição [...]". A empresa seria comandada por “homens respeitaveis", tais como o médico Dr. Candido Barata Ribeiro, o capitalista Cremilde Barata, Athanagildo Barata Ribeiro, ex-tenente da armada e "hoje constructor" e João Maria Teixeira de Mello, "capitalista negociante". A empreitada seria louvável e o país precisaria de "homens de tal quilate", que "com sacrificio de capitaes e risco de vida, pretendem explorar a industria nascente de botocudos" (Gazeta de Noticias, 1882g, p. 2). Athanagildo passa a assinar uma serie de cartas publicadas ao longo de dez dias pelo Jornal do Commercio, atacando a imprensa da corte, afirmando que "este assumpto está destinado a prender a attenção do universo", uma vez que a imprensa coloca o público "contra os crueis traficantes que transportárão Botocudos á Europa!". Athanagildo acusa a Gazeta de Noticias de ter um tom "folgasão e chocalheiro", tendo se colocado como a primeira a denunciar o fato, "como se dissesse [...] as alvigaras são minhas!... Compra-me... Compra-me, que eu me vendo exactamente para isso". Segundo Athanagildo 
"o pensamento de levar Botocudos á Europa estava ha muito concebido, era o corolario de um plano complexo e do qual nos vamos occupar". Nessa "penosa viagem" ele visitou de pequenos centros indígenas ao aldeamento do Mutum. Dali teria descido "pelo Rio-Doce [...], acompanhado por cinco Botocudos, que voluntariamente o seguião" (Jornal do Commercio, 1882b, p. 3).
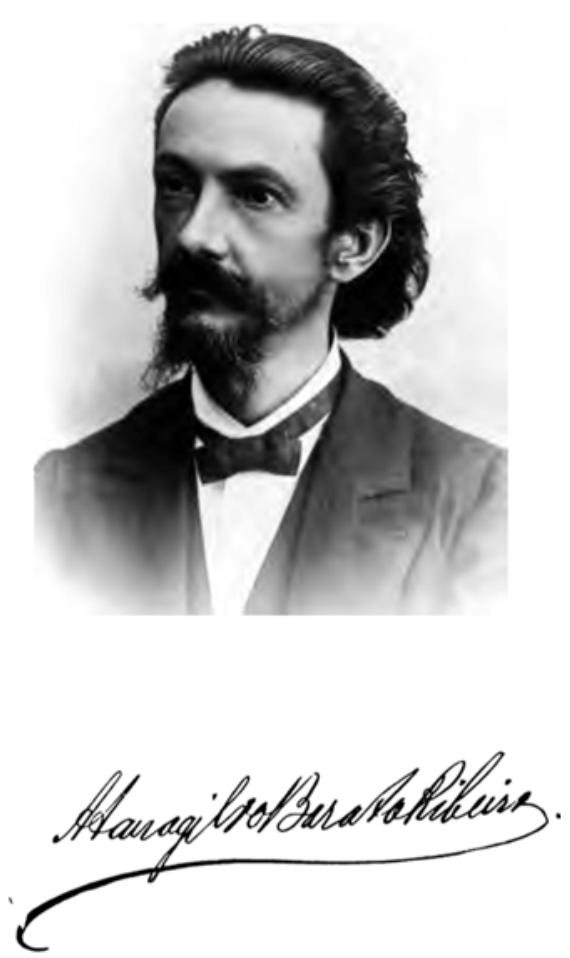

Figura 5. Fotografia de Athanagildo Barata Ribeiro (Ribeiro, 1895, contracapa).

O Jornal do Commercio não apenas cede espaço para que Atanagildo publique suas cartas, como também publica artigos assinados pelo seu próprio editorial criticando a maneira como a imprensa da corte, salvo raras exceções, estaria sempre disposta a calúnias e difamações. No entanto, tanto o governo quanto a opinião pública parecem se colocar contra o envio dos Botocudos para Londres. 
Em 17 de dezembro de 1882, o governo expede um telegrama para os portos estrangeiros, ordenando que os Botocudos embarcados no porto de Vitória sejam imediatamente reembarcados de volta ao Brasil. A Gazeta de Noticias (1882h, p. 1) de mesma data comemora o telegrama e de forma anedótica conclui: "não ha rifão mais certo do que aquelle que diz: - o barato sai caro". Esse é o começo de uma série de notícias, pequenos poemas e outras anedotas que fazem trocadilho com o sobrenome Barata, publicados pela gazeta.

O editorial do Jornal do Commercio chama os jornais de oposição de "forjadores de graves acontecimentos" que aceitam para proveito do seu negócio "noticias de sensação", com o intuito de impingir "ao publico o romance tenebroso dos botocudos, com os indispensaveis rapto, mulher abandonada na praia deserta, navio no largo, contrabandistas, motim popular". Argumenta-se que "dous negociantes honestos" não seriam tão insensatos a dispor de recursos próprios e de crédito "para irem na Europa representar de saltimbancos de feira ou emprezarios de barraca". Apesar de os jornais terem exagerado nas verbas que relataram com a viagem, teriam deixado de falar de outras despesas, que dariam um total de "cincoenta a sessenta contos", argumentando em seguida "e pensão [...] que haja alguem bastante ingenuo para fazer traficancia por esse preço, indo mostrar bugres na Europa? Ainda se os indios fossem tenores..." A empresa seria importante para o país, tendo em mira lucros lícitos e proporcionais aos capitais investidos, mas "infelizmente a leviandade dos pregoeiros de escandalos obrigará os dous honrados Brazileiros a desvendarem o seu plano, que, uma vez conhecido, ficará exposto á concurrencia de uns e á malevolencia de outros". O autor complementa que se de fato for verdade que o governo "mandou apprehender os indios, devem-se regosijar da sua obra os sisudos jornalistas". O plano em vista teria sido frustrado graças a uma "macula original: era de dous Brazileiros", e a "plebe nacional" não teria o direito de supor "povoar as margens do Rio Doce, e de levar a vida e a civilisação aos sertões abandonados", pois o que mereceria "o traficante brazileiro, mordido de tamanha ambição, é ser traspassado pela flecha do indio, como disse um patriota da rua do Ouvidor" (Jornal do Commercio, 1882c, p. 2, grifo no original).

Na guerra pela opinião pública vislumbra-se que o público não estaria do lado dos irmãos Barata Ribeiro e do Jornal do Commercio. Tanto Athanagildo refere-se ao "constrangimento" e "descrédito" pelos quais estaria passando, fomentados por "certos órgãos da imprensa", quanto se testemunha que, na rua 
do Ouvidor, falava-se com inflamação sobre o tema, desejando os transeuntes que os Baratas Ribeiros recebessem flechadas de índios. É notável também que, durante o carnaval de 1883, o Clube Democráticos desfilasse um carro com foliões fantasiados de Botocudos aprisionados em um gaiola e regidos por uma barata.

Durante as cartas que escreve ao Jornal do Commercio, Athanagildo presta-se a dar detalhes da sua viagem até o Espírito Santo e a atacar a Gazeta de Noticias, mas ele pouco explica os planos da Companhia Industrial do Rio Doce com os Botocudos. É na sua última carta que ele expõe abertamente os planos de construir um museu em Londres, com o intuito de atrair investimentos industriais, estradas de ferro e colonos para a região do Rio Doce. Afirma restar-lhe o papel de "satisfazer a curiosidade banal ou indiscreta" que exigia "explicações sobre os negocios particulares que determinárão a viagem" (Jornal do Commercio, 1882d, p. 3). Deveriam ter sido levados "não cinco ou seis botocudos, mas 50 ou 60, o que se não realisou por difficuldades de occasião". Os objetivos da empresa teriam sido frustrados pela imprensa, porque antes que tivessem pedido a concessão do governo, um outro projeto foi aprovado que os teria feito desistir da construção da ferrovia. Tinham o intuito de "inspirar confiança á immigrantes inglezes", convencê-los "de que as margens do Rio Doce contém riquezas naturaes" e "provar que os indigenas não constituem o perigo que se suppõe na Europa. [...]. Para isso era necessario mostrar que o indigena é capaz de trabalhar, tem industrias, póde civilisar-se" (Jornal do Commercio, 1882d, p. 3). Cremilde Barata Ribeiro desde há algum tempo teria colecionado artefatos e curiosidades indígenas, "alguns dos quaes forão expostos no musêo" e teria embarcado para a Europa com artefatos adquiridos no Pará e mais quatro províncias, para "constituir um musêo indigena digno de ser apresentado na Europa", sobre "oito ou dez tribus". Seria conveniente que "ao lado do producto apparecesse o productor como a demonstração viva de que o indigena não é refractario á civilisação". A raça americana estaria destinada a "collaborar nos destinos do novo mundo", principalmente o Brasil, com territórios de "enormes solidões que estão pedindo população", ao passo que "o velho mundo pede espaço por já não poder conter a onda crescente de proletarios que ameaça derrocar as bases da propria sociedade" (Jornal do Commercio, 1882d, p. 3). Segundo Athanagildo:

[...] o musêo completava-se com a presença do indio, e o Sr. Cremilde só lamentou não poder levar 50 ou 60 que representassem a raça em todas as idades e 
variantes da especie. [...] Eis ahi o fim, o intuito industrial da viagem, a que se ligava, menos por precisão nossa do que pelas forças das circumstancias um interesse scientifico, qual o de ser o musêo particular um como annuncio e prologo da grande exposição antropologica americana, em que o Brazil deve representar papel importante. (Jornal do Commercio, 1882d, p. 3).

A coleção que Cremilde levara à Inglaterra teria sido composta por objetos que ele cedera ao Museu Nacional, bem como "coleções mais completas" de "artefatos e curiosidades indígenas", tendo ele mesmo percorrido o Espírito Santo, bem como enviado emissário ao Pará. Nesta última carta Athanagildo, em tentativa de justificar a sua empreitada, critica a forma de colonização indígena empregada até então pelo governo e "os rios de dinheiro que o Estado tem despendido em pura perda". Essa crítica basta para que o governista Jornal do Comercio manifestasse-se contrariamente aos irmãos Barata Ribeiro. Em artigo assinado sob o pseudônimo de "Cacique" (seria Dom Pedro II?), o Jornal do Commercio não só critica os seus antigos aliados, como encerra o assunto, recusando-se a voltar a ele. Em tom jocoso, o autor é assertivo ao afirmar que "os emprehendedores emprezarios" que "gastárão avultados capitaes, saude, conhecimentos technicos" e que "assim trabalhavão, e já tudo fazia crer n'um futuro risonho, quando vem a tagarella imprensa e com mãos sacriligas rasga o mysterioso vêo que encobria o vergonhoso segredo" (Jornal do Commercio, 1882e, p. 1, grifo no original). Se o "paternal governo" repudia "os seus mais dilectos filhos [...] como se se tratasse de miseras baratas", lembra o autor o fato de que o estaleiro dos Barata Ribeiro tem contratos com o mesmo governo, afirmando ironicamente que "muita razão tem a distincta familia em flagellar esse governo, que não deveria ignorar ser competente unicamente para contractar cruzadores". Conclui o autor:

E assim morreu no nascedouro essa gigantesca empreza, verdadeira saltimbanca, trajada com as gallas anthropologicas.

E assim voltão as trévas, genios fecundos como os Srs. Baratas.

Com toda a justiça, em seu ultimo artigo, os Srs. Baratas lançárão aos quatros ventos, Ó ingrata patria não possuirá as nossas caveiras!!!

Recebão os nosso pezames e evitem a imprensa por que, quem com ferro fere com ferro será ferido e aceite tambem os pezames do Cacique. (Jornal do Commercio, 1882e, p. 1, grifo no original). 


\section{“Temos pena, não dos Botocudos, mas do Brazil"}

A Revista Illustrada (1882e, p. 4-5) traz ilustração sequencial do envio dos Botocudos à Europa. A questão dos Botocudos é narrada em duas páginas, com a intermitência de outros assuntos. $O$ primeiro quadro sobre os índios mostra a proa de um navio, com uma índia e dois índios nus passando mal e vomitando no mar (ver Figura 6).

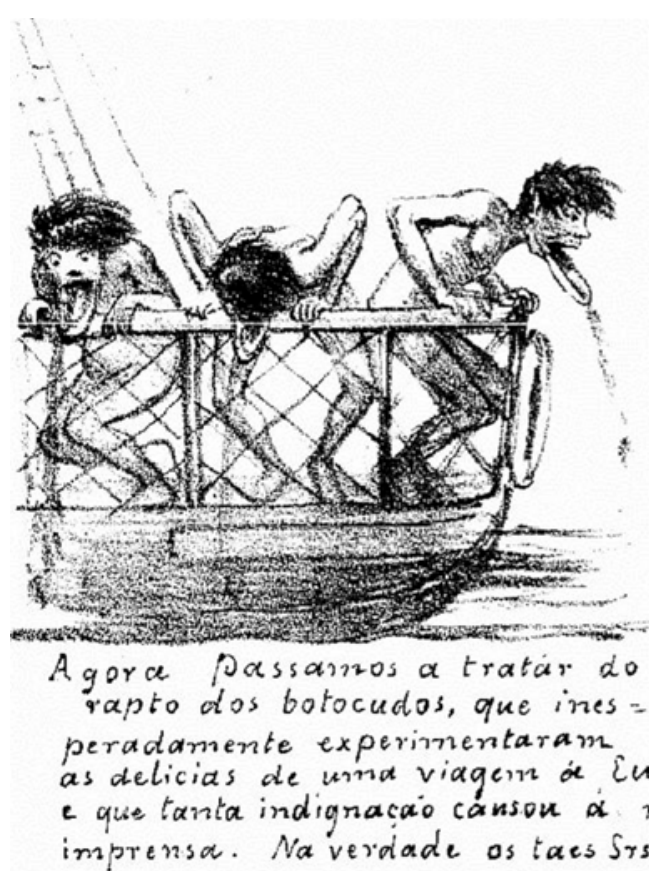

Figura 6. Revista Illustrada (1882e, p. 4).
Abaixo da imagem lê-se: "Agora passamos a tratar do rapto dos botocudos, que inesperadamente experimentaram as delicias de uma viagem á Europa, e que tanta indignação causou á nossa imprensa. Na verdade os taes Srs. Baratas, raptores dos..." (Revista Illustrada, 1882e, p. 4) A narrativa sobre os Botocudos foi quebrada, porque bateu à porta da edição mais um assinante da revista (Agostini tenta construir uma sequência sobre os Botocudos, mas é a todo tempo interrompido, demonstrando cansaço em ter que ser produtivo e cumprir os prazos de entrega da revista).

No quadro seguinte (ver Figura 7), o narrador expressa:

Voltamos aos botocudos. É sabido que o fim dos raptores, era expôl-os á curiosidade dos parisienses em algum barracão á 4 vintens a entrada. Já estamos ouvindo o seguinte: Entrez Mesdames et Messieurs et regardez ce specimen de la race bresilienne; cez feroces cannibales, veritables anthropophages, a quí il faut un colon par jour pour dejeuner! Entrez Mesdames et vous verez des gueules a faire envie aux crocodiles. etc, etc, et alle la musique. (Revista Illustrada, 1882e, p. 4-5, grifo no original). 
Esse quadro mostra uma multidão formando fila à entrada do local de exposição. Na parede existem cartazes, no primeiro deles está escrito "Entrèe 20 cent" e no segundo e de maior destaque há a imagem do busto de dois Botocudos, um de frente e outro de perfil, onde se lê "Grande Exposition des Botocudós. Sauvages e antropophages bresiliens". À frente do local de exposição há uma banda em um pequeno palco e um homem com batuta de maestro na mão, elegante casaca de abotoaduras e chapéu de pompa: eis o apresentador, de quem ouvimos a chamada para entrar na "Grande Exposition". A multidão é representada de costas, aguardando na longa fila.

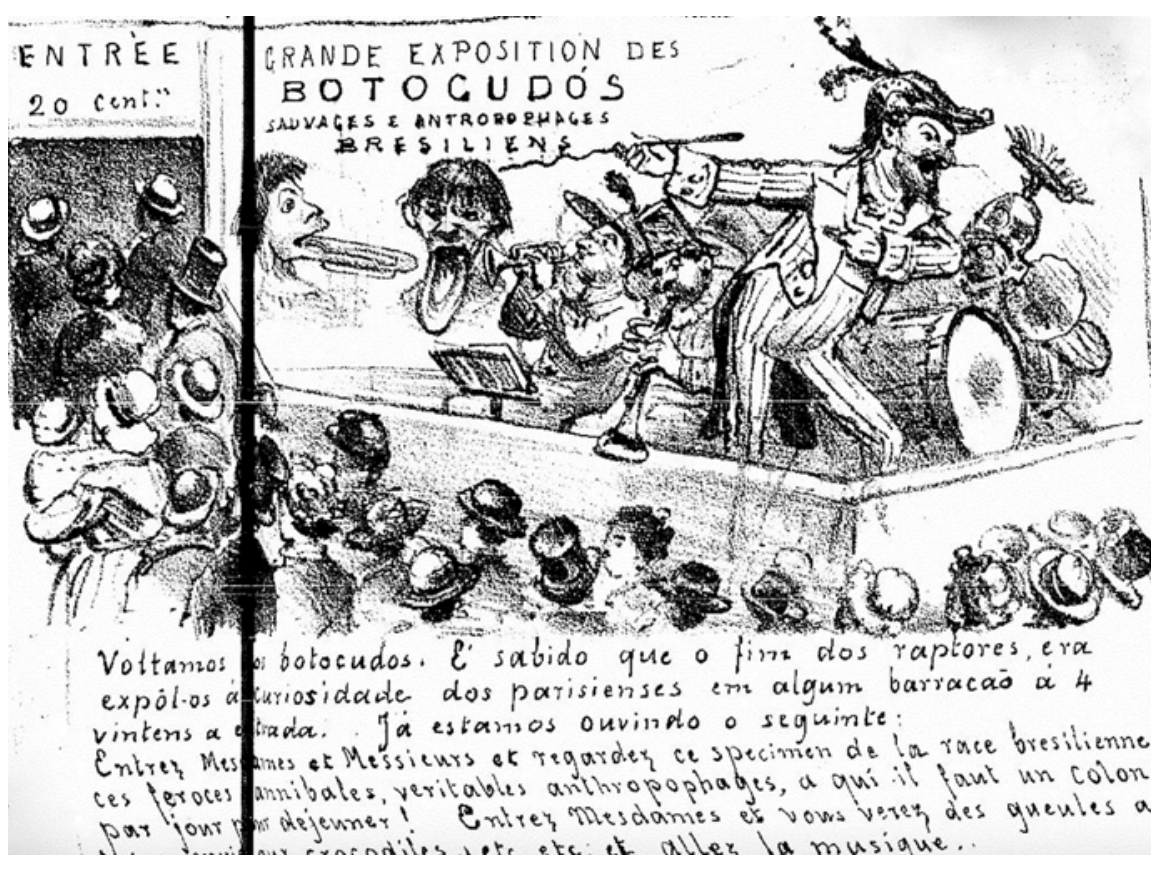

Figura 7. Revista Illustrada (1882e, p. 4-5).

O quadro seguinte mostra a multidão de frente, horrorizada com a visão dos índios, dois homens e uma mulher que, colocados em um púlpito e sentados em um banco, assustam os parisienses com suas orelhas e lábios alargados (ver Figura 8). O público está separado dos índios por uma pequena grade. Os que estão na frente jogam seus corpos para trás, como se tentassem fugir de tal 
aparição, enquanto a multidão do fundo força caminho para vê-los. Paris está literalmente boquiaberta. Essa é a expressão geral do público, de bebês e crianças a damas e cavalheiros. Mas há também a chacota, que pode ser lida na expressão de dois homens colocados na primeira fileira, que em pé observam os Botocudos.

Os índios sentados parecem impassíveis, talvez alheios à razão de por que causam horror ao público. Abaixo da imagem, afirma o narrador:

Tem razão a nossa imprensa de se ter indignado contra uma tal offensa á dignidade de cidadãos tão distinctos, expostos ás gargalhadas dos europeos. Nós pensamos diversamente dos collegas. Temos pena, não dos Botocudos, mas do Brazil, representado por esses legitimos patricios, que causarão grande espanto á uns, desmamamento geral nas crianças e serios perigos nas mulheres gravidas!... (Revista Illustrada, 1882e, p. 5).

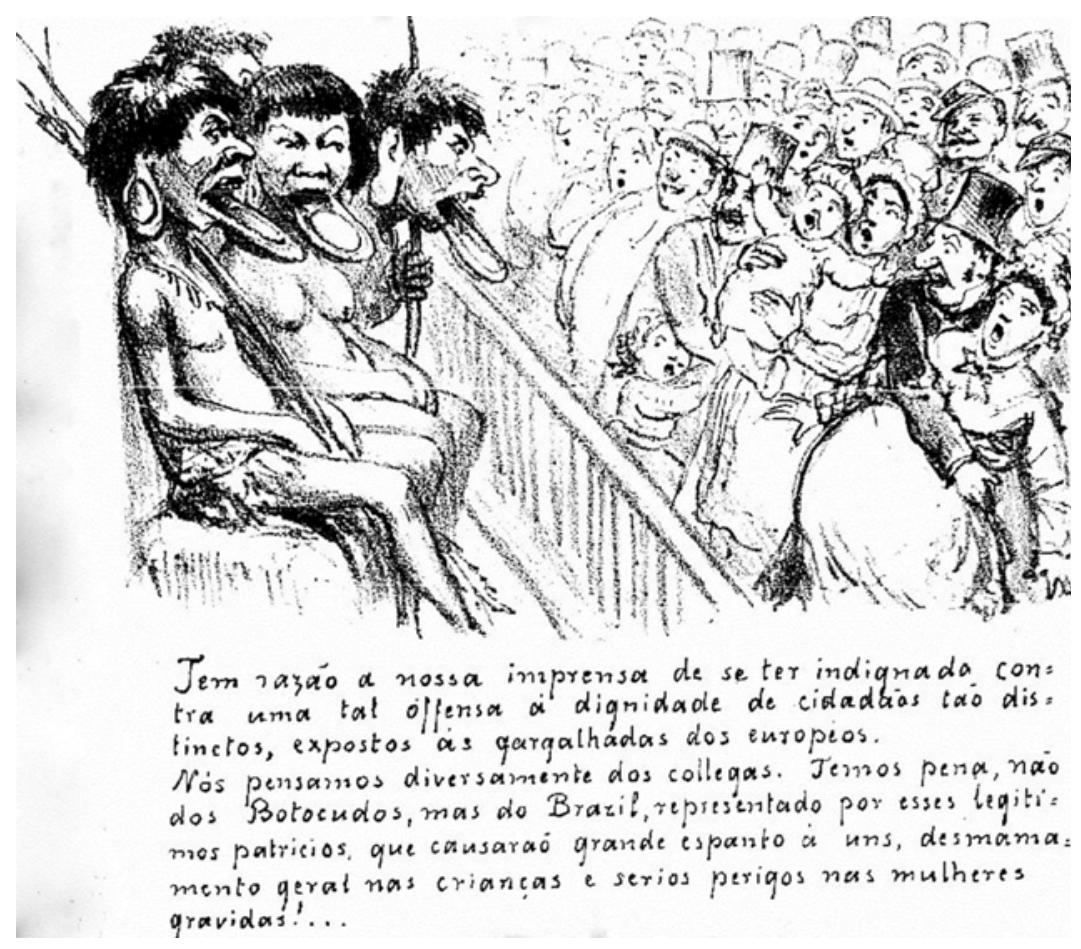

Figura 8. Revista Illustrada (1882e, p. 5). 
O quadro seguinte mostra um índio e um negro sentados em um banco, sendo exibidos pelo mesmo apresentador de casaca de abotoaduras e chapéu de pompa (ver Figura 9). O Botocudo de dentes afiados, lábios e orelhas alargadas, carrega nos braços um arco e flecha, e olha de forma ameaçadora para o público, enquanto o negro parece triste e ensimesmado, com o olhar voltado para baixo e uma enxada nas mãos. $O$ público com tralhas e bolsas assusta-se, e tenta fugir do local, eis que eram os possíveis colonos a vir para o Brasil. Abaixo da imagem, o narrador afirma: "E que attractivo para os colonos que devem vir salvar a nossa lavoura! N'um paiz, dirão elles, onde ha escravos desta côr e homens livres deste feitio, ... é porque lá não vamos" (Revista Illustrada, 1882e, p. 4).

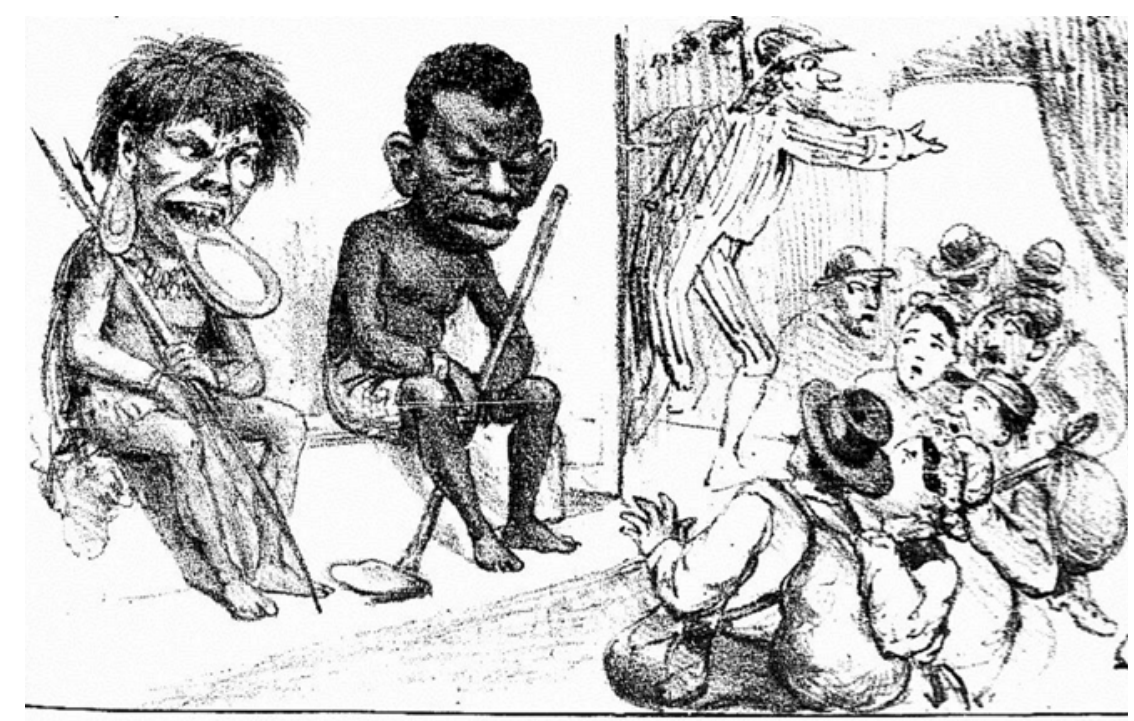

C que attractivo para os colonos que devern vir saluar a nossa bavonto $\mathcal{N}$ 'um paix, dirajo elles, onde ha escravos desta cör e homens livres deste feitio,... e poraue $l_{\alpha} \dot{\alpha}$ naio vamos.

Figura 9. Revista Illustrada (1882e, p. 4).

No quadro seguinte, Dom Pedro II, bem como a alguns homens do seu governo, estão representados como Botocudos, com alargadores, penachos, colares e 
tangas. Dom Pedro II usa cocar de cacique, lança e manto imperial, até mesmo o arlequim da Revista Illustrada aparece com lábio alargado (ver Figura 10). O narrador afirma: "Na verdade, se os européos suppóem que os cidadãos livres do Imperio são assim, que bella figura fazemos todos, á começar pelo imperial Cacique, até nós, o mais humilde e selvagem de seus subditos!... que grande pandega!" (Revista Illustrada, 1882e, p. 4-5).

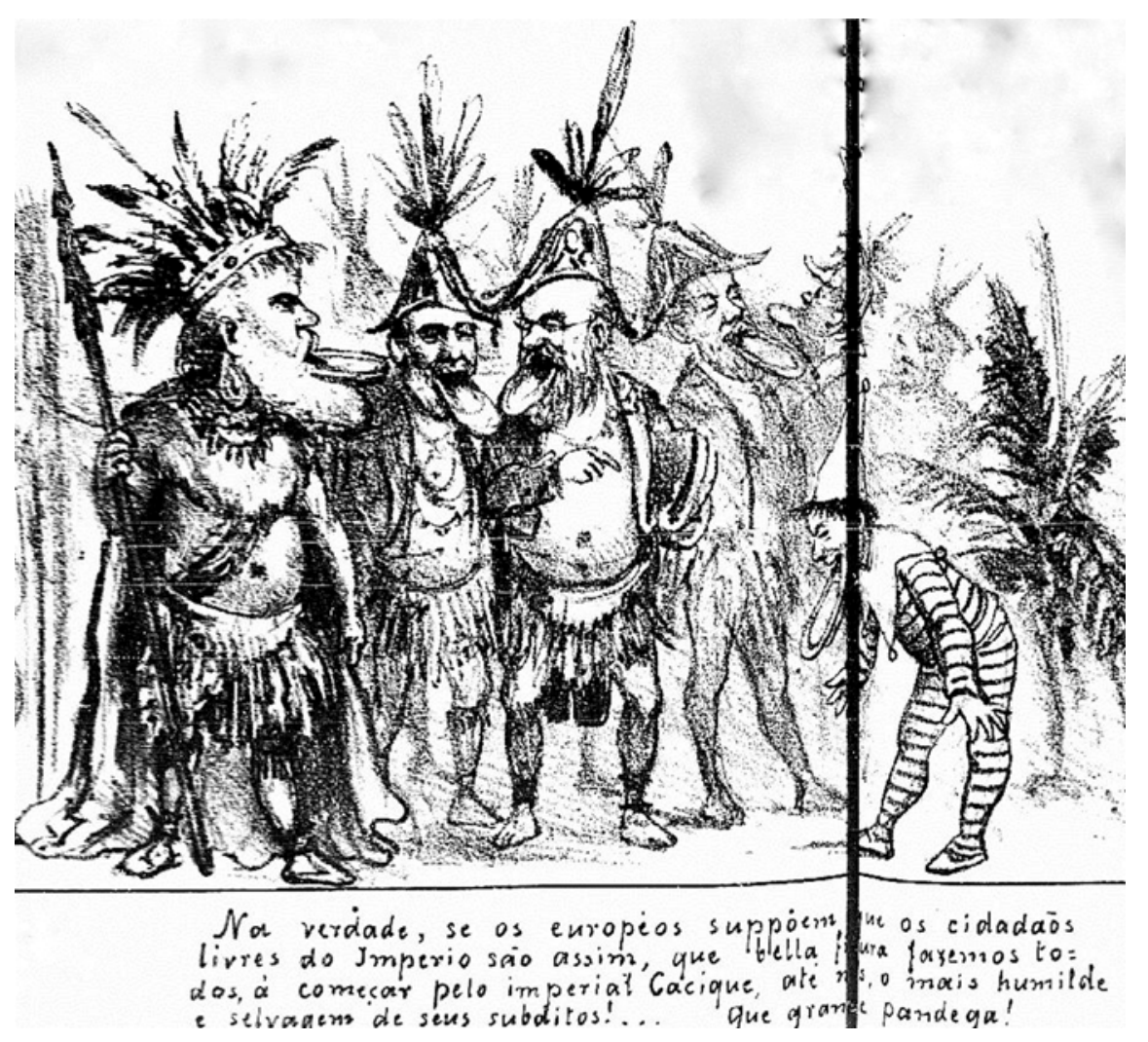

Figura 10. Revista Illustrada (1882e, p. 4-5).

No quadro seguinte, três índios são acolhidos sob o manto da imprensa, que aqui é representada como uma mulher com cabeça em formato de coração, com 
vestido e manto virginais e uma grande pena de escrita na mão (ver Figura 11). $\mathrm{Na}$ barra de seu vestido está escrito: imprensa fluminense. O arlequim apresenta a cena com seu braço direito e ri do que vê, enquanto o narrador afirma: "Por isso não fazemos côro commum com os illustres collegas, que entenderam transformar a imprensa em symbolo da Caridade, estendendo o seu manto protector sobre esses desgraçados selvagens. Achamos muita graça e não podemos conter uma boa gargalhada, considerando..." (Revista Illustrada, 1882e, p. 5). $E$ aqui a narrativa é mais uma vez interrompida por alguns leitores que batem à porta da revista para assiná-la. O arlequim despede-se dizendo que com tantas assinaturas não lhe deixam tempo de acabar esse número da revista.

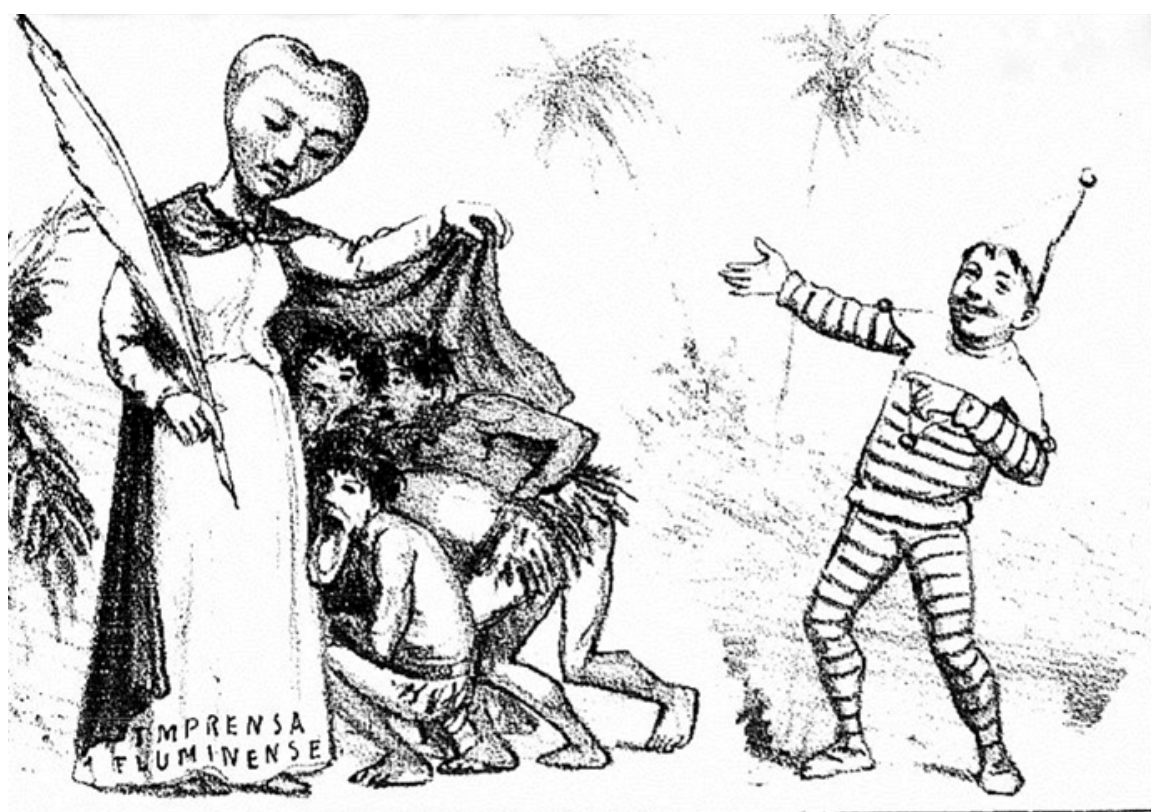

Por isso najo faxenos coro commun comz os illustres collegas, que entenderan transformar imprensa em symbolo da Caridade, estenderdo o sen manto proiector yobre esses desgra, cados selvagens. Achamos muita graça e nao podemos conier unza boa gargalhada, c

Figura 11. Revista Illustrada (1882e, p. 5). 
Se na pena de Agostini a imprensa da corte é representada como caridosa, vale lembrar que a Gazeta de Noticias (1883, p. 1) volta a falar da questão dos Botocudos quando a exposição é inaugurada em Londres, em maio de 1883, muito mais para revelar "a noticia exacta do que foram fazer os botocudos na Europa", e demonstrar que havia estado ao lado da verdade. Apesar do fulgor com que o debate em torno da questão dos Botocudos foi aberto em novembro de 1882, ao final do ano de 1883 já não se ouvia mais falar dos Botocudos enviados à Europa.

\section{Conclusões}

A Exposição Antropológica Brasileira, promovida pelo Museu Nacional em 1882, teve como intuito a construção de uma imagem de nação moderna, o retrato de um Segundo Império que investia em suas instituições científicas. Nessa exposição os Botocudos representavam por definição "o outro" antropológico, a imagem que espelha exatamente o contrário do Brasil civilizado. Enquanto a imagem de um Brasil indigenista é cultivada pelo romantismo e Estado brasileiro, os indígenas reais são dizimados, em detrimento de índios míticos (Cunha, 1992). O projeto de construção de uma identidade nacional de afinidade com índios tupi (representados como bons selvagens), compreendia também um processo civilizador, capaz de dominar os bravos Botocudos. Ao passo em que eram dizimados ou submetidos ao processo de colonização e aldeamento nos longínquos sertões, os Botocudos eram expostos na corte. ${ }^{24}$

Paradoxalmente, o mesmo processo de modernização que conduzia ao extermínio indígena utilizava de aparato técnico científico para a exibição e preservação da imagem desses povos, em vias de desaparecimento. Até hoje estão expostas no Museu Nacional esculturas de índios botocudos e xerente, feitas a partir dos moldes dos índios levados para a corte. Tais esculturas podem ser entendidas como representações das violências por que passaram esses índios, embora em seu contexto de exposição essas violências não

24 Processo parecido aconteceu durante a guerra e extermínio dos povos Hereró, ao longo do processo de colonização alemã na Namíbia. Enquanto o império de Guilherme II conduzia o hoje reconhecido extermínio dos Hereró, zoológicos humanos eram montados longe dos campos de batalha na África, para que nas grandes cidades alemãs o público pudesse ver os temidos guerreiros. Ver Thode-Arora (2004) e Zeller (2004). 
estejam nem visibilizadas, nem problematizadas. Tais esculturas entram na categoria política de "coleções sensíveis", ${ }^{25}$ que coloca uma série de questões éticas à exposição de objetos, tais como os "restos mortais".

A Exposição Antropológica do Museu Nacional e a sua subsequente exposição londrina demonstram os fluxos entre a aquisição de coleções etnográficas, discursos, narrativas museais e formas de entretenimento populares, como os zoológicos humanos. Cremilde Barata Ribeiro havia contribuído com sua coleção particular ao Museu Nacional, e em seguida é esta instituição que, mesmo indiretamente, contribui para a Exposição Antropológica Brasileira em Londres. Os irmãos Barata Ribeiro copiam não apenas o título, bem como temática e narrativas, além de utilizar membros da mesma trupe ou "família" de Botocudos.

Vitrine de um Brasil moderno e evento científico mais importante do Brasil oitocentista, a versão não oficial da Exposição Antropológica Brasileira, promovida em Londres pelos irmãos Barata Ribeiro, foi capaz de produzir uma rachadura no espelho diante do qual o Brasil gostaria de se ver. A partir daqui outras imagens são refletidas: jornais e intelectuais da época passam a se perguntar “o que pensam de nós na Europa?", espelhando um Brasil que vê a si mesmo através dos olhos ingleses, uma identidade nacional construída a partir de um "outro" interno, os Botocudos, e um "outro" externo, a Europa. Diante desse espelho duplo, nas palavras de Agostini, era mais para se ter pena "não dos Botocudos, mas do Brazil", que, sentado à porta da modernidade, pedia para entrar, mas não suportava a sua própria imagem. ${ }^{26}$

25 Britta Lange (2011) argumenta que tanto restos mortais quanto os moldes, e até mesmo as vozes (guardadas em fonógrafos), de sujeitos submetidos a inspeções antropométricas podem ser entendidos como parte de "coleções sensíveis", na medida em que são índices que os representam. Há que argumentar que nas longas e penosas seções os sujeitos tinham que ficar imóveis durante a secagem do gesso para a confecção das esculturas das coleções etnográficas. Durante a feitura dos moldes de rostos as pessoas ficavam sem respirar, havendo relatos de sujeitos que pensaram que iriam morrer em tais seções.

26 Postscriptum ao artigo submetido à publicação: que descansem em paz os traços de suas coleções sensíveis e parte da memória de Joaquim Pedro, José, Nazareth, Thomé, Maréca, Aquinhen e Benta, os índios nak-nanuk expostos no ano de 1882 no Rio de Janeiro. Que seus objetos e memória tenham encontrado descanso nesta segunda morte que significou o incêndio no Museu Nacional na noite de 2 de setembro de 2018. 


\section{Referências}

AGOSTINHO, M. A Exposição Antropológica Brasileira de 1882: práticas de colecionamento e circulação de indígenas no Museu Nacional. In: ENCONTRO ANUAL DA ANPOCS, 41., Caxambu, 2017. Anais [...] São Paulo: Anpocs, 2017. Disponível em: https://www.anpocs.com/index.php/papers-40-encontro-2/gt-30/gt04-20/10622-a-exposicao-antropologica-brasileira-de-1882-praticas-de-colecionamento-e-circulacao-de-indigenas-no-museu-nacional/file. Acesso em: 20 jan. 2018.

ALTICK, R. The shows of London. Cambridge: Harvard University Press, 1978.

AMES, E. Carl Hagenbeck's empire of entertainments. Seattle: University of Washington Press, 2008.

ANDERMANN, J. Espetáculos da diferença: a Exposição Antropológica Brasileira de 1882. Topoi, v. 5, n. 9, p. 129-170, 2004.

ANDERMANN, J. The optic of the state: visuality and power in Argentina and Brazil. Pittsburgh: University of Pittsburgh Press, 2007.

AYRES, J. Ao publico e ao Exmo. Sr. Conselheiro Ladisláo Netto. O Espirito-Santense, Victoria, anno 12, n. 61, p. 4, 3 ago. 1882.

BLANCHARD, P. et al. (dir.). Zoos humains: de la Vénus hottentote aux reality shows. Paris: La Découverte, 2002.

BORGES, L. C.; BOTELHO, M. B. Positivismo e artes plásticas: o Museu Nacional e a I Exposição Antropológica Brasileira. In: ENCONTRO NACIONAL DE PESQUISA EM CIÊNCIA DA INFORMAÇÃO, 13., Rio de Janeiro, 2012. Anais [...] 2012. Disponível em: http://enancib.ibict.br/index.php/enancib/xiiienancib/paper/viewFile/3927/3050. Acesso em: 20 jan. 2018.

CUNHA, M. Política indigenista no século XIX. In: CUNHA, M. História dos índios no Brasil. São Paulo: Companhia das Letras, 1992. p. 133-154.

DANTAS, R. Casa Inca ou Pavilhão da Amazônia?. 2012. Tese (Doutorado em História das Ciências, das Técnicas e Epistemologia) - Centro de Ciências Matemáticas e da Natureza, Universidade Federal do Rio de Janeiro, Rio de Janeiro, 2012.

O DESPERTADOR. Desterro, anno 20, n. 2013, 8 jul. 1882a.

O DESPERTADOR. Desterro, anno 20, n. 2022, 9 ago. 1882b.

DIARIO DE PERNAMBUCO. Recife, anno 58, n. 179, 8 ago. 1882.

DIARIO DO BRAZIL. Rio de Janeiro, anno 2, n. 151, 7 jul. 1882a. 
DIARIO DO BRAZIL. Rio de Janeiro, anno 2, n. 261, 16 nov. 1882b.

ECHO DO POVO. Juiz de Fóra, anno 1, n. 11, 13 ago. 1882.

O ESPIRITO-SANTENSE. Victoria, anno 12, n. 61, 3 ago. 1882.

GAZETA DE NOTICIAS. Rio de Janeiro, anno 6, n. 162, 13 jun. 1880.

GAZETA DE NOTICIAS. Rio de Janeiro, anno 8, n. 188, 9 jul. 1882a.

GAZETA DE NOTICIAS. Rio de Janeiro, anno 8, n. 199, 20 jul. 1882b.

GAZETA DE NOTICIAS. Rio de Janeiro, anno 8, n. 215, 4 ago. 1882c.

GAZETA DE NOTICIAS. Rio de Janeiro, anno 8, n. 217, 6 ago. 1882d.

GAZETA DE NOTICIAS. Rio de Janeiro, anno 8, n. 243, 1 set. 1882e.

GAZETA DE NOTICIAS. Rio de Janeiro, anno 8, n. 328, 25 nov. $1882 \mathrm{f}$.

GAZETA DE NOTICIAS. Rio de Janeiro, anno 8, n. 344, 11 dez. 1882g.

GAZETA DE NOTICIAS. Rio de Janeiro, anno 8, n. 350, 17 dez. 1882h.

GAZETA DE NOTICIAS. Rio de Janeiro, anno 9, n. 196, 15 jul. 1883.

GUIA da Exposição Anthropologica Brazileira realisada pelo Museu Nacional do Rio de Janeiro a 29 de julho de 1882. Rio de Janeiro: Typographia de G. Leuzinger \& Filhos, 1882.

JORNAL DO COMMERCIO. Rio de Janeiro, anno 61, n. 182, 2 jul. 1882a.

JORNAL DO COMMERCIO. Rio de Janeiro, anno 61, n. 347, 14 dez. 1882b.

JORNAL DO COMMERCIO. Rio de Janeiro, anno 61, n. 352, 19 dez. 1882c.

JORNAL DO COMMERCIO. Rio de Janeiro, anno 61, n. 357, 24 dez. 1882d.

JORNAL DO COMMERCIO. Rio de Janeiro, anno 61, n. 358, 25 dez. 1882e.

KEULLER, A. Os estudos físicos de antropologia no Museu Nacional do Rio de Janeiro. 2008. Tese (Doutorado em História Social) - Faculdade de Filosofia, Letras e Ciências Humanas, Universidade de São Paulo, São Paulo, 2008.

KOLOS, A. Imagining otherness: the pleasure of curiosity in the Middle Ages. Mirabilia, v. 18, n. 1, p. 137-150, 2014.

LANGE, B. Sensible Sammlungen. In: BERNER, M.; HOFFMANN, A.; LANGE, B. Sensible Sammlungen: aus dem anthropologischen Depot. Hamburg: Philo Fine Arts, 2011. p. $15-40$. 
O MEQUETREFE. Rio de Janeiro, anno 8, n. 283, 20 ago. 1882.

MONTEIRO, J. M. As "raças" indígenas no pensamento brasileiro do império. In: MAIO, M. C.; SANTOS, R. V. (org.). Raça, ciência e sociedade. Rio de Janeiro: Editora Fiocruz: CCBB, 1996.

NASCIMENTO, F. A formação da coleção de indústria humana no Museu Nacional, século XIX. 2009. Tese (Doutorado em Antropologia Social) - Museu Nacional, Universidade Federal do Rio de Janeiro, Rio de Janeiro, 2009.

A PATRIA. Rio de Janeiro, anno 25, n. 51, 8 ago. 1882.

PRATT, M. Os olhos do império: relatos de viagens e transculturação. Bauru: Edusc, 1999.

A PROVINCIA DO ESPIRITO-SANTO. Victoria, anno 1, n. 44, 28 jun. 1882.

RANKEL, L. A construção de uma memória para a nação: a participação do Museu Paranaense na Exposição Antropológica Brasileira de 1882. 2007. Dissertação (Mestrado em História) - Setor de Ciências Humanas, Universidade Federal do Paraná, Curitiba, 2007.

RELATORIO com que o Exm. Sr. Dr. Herculano Marcos Inglez de Souza entregou no dia 9 de dezembro de 1882 ao Exm. Sr. Dr. Martim Francisco Ribeiro de Andrada Junior a Administração da Provincia do Espirito-Santo. Victoria, 1882.

REVISTA ILLUSTRADA. Rio de Janeiro, anno 7, n. 310, 1882a.

REVISTA ILLUSTRADA. Rio de Janeiro, anno 7, n. 311, 1882b.

REVISTA ILLUSTRADA. Rio de Janeiro, anno 7, n. 313, 1882c.

REVISTA ILLUSTRADA. Rio de Janeiro, anno 7, n. 318, 1882d.

REVISTA ILLUSTRADA. Rio de Janeiro, anno 7, n. 326, 1882 e.

RIBEIRO, A. Sonho do cárcere: dramas da Revolução de 1893 no Brazil. Rio de Janeiro: Casa Mont'Alverne, 1895.

SÁ, G. et al. Crânios, corpos e medidas. História, Ciências, Saúde-Manguinhos, Rio de Janeiro, v. 15, n. 1, p. 197-208, jan./mar. 2008.

SANTO AGOSTINHO. Confissões. São Paulo: Nova Cultural, 1999.

SCHWARCZ, L. O espetáculo das raças. São Paulo: Companhia das Letras, 1993.

SCHWARCZ, L. As barbas do imperador: D. Pedro II, um monarca nos trópicos. São Paulo: Companhia das Letras, 1998. 
SCHWARCZ, L.; DANTAS, R. O Museu do Imperador: quando colecionar é representar a nação. Revista do IEB, n. 46, p. 123-164, 2008.

SILVA, A. O Rio de Janeiro continua índio: território do protagonismo e da diplomacia indígena no século XIX. 2016. Tese (Doutorado em Memória Social) - Centro de Ciências Humanas e Sociais, Universidade Federal do Estado do Rio de Janeiro, Rio de Janeiro, 2016.

THODE-ARORA, H. Für fünfzing Pfenning um die Welt. Frankfurt: Campus Verlag, 1989.

THODE-ARORA, H. Afrika-Völkerschauen in Deutschland. In: BECHHAUS-GERST, M.; KLEIN-ARENDT, R. (Hg.). Afrikanerinnen in Deutschland und schwarze Deutsche: Geschichte und Gegenwart. Münster: Lit Verlag, 2004. p. 25-40.

ZELLER, J. Die Leiche im Keller: Eine Entdeckungsreise ins Innerste der Kolonialmetropole Berlin. In: BECHHAUS-GERST, M.; KLEIN-ARENDT, R. (Hg.). Afrikanerinnen in Deutschland und schwarze Deutsche: Geschichte und Gegenwart. Münster: Lit Verlag, 2004. p. 89-108.

Recebido: 28/01/2018 Aceito: 12/07/2018 | Received: 1/28/2018 Accepted: 7/12/2018 